\title{
Crystallisation and zircon saturation of calc-alkaline tonalite from the Adamello Batholith at upper crustal conditions: an experimental study
}

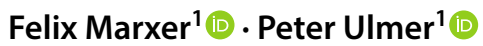

Received: 25 April 2019 / Accepted: 16 September 2019 / Published online: 3 October 2019

(c) The Author(s) 2019

\begin{abstract}
The understanding of the geochemical and petrophysical evolution of magmas forming intermediate calc-alkaline batholiths at shallow crustal levels critically depends on knowledge of the phase equilibria relations along the liquid line of descent. Here, we present experimental results for a tonalitic system at a pressure of $200 \mathrm{MPa}$ and under water-saturated conditions. Melting experiments were performed at temperatures between 700 and $1000{ }^{\circ} \mathrm{C}$ in externally heated HCM pressure vessels, with oxygen fugacity controlled close to the $\mathrm{Ni}-\mathrm{NiO}$ buffer equilibrium (NNO) employing an argon-methane mixture as pressure medium and $\mathrm{Co}-\mathrm{Pd}$ redox sensors to verify $\mathrm{fO}_{2}$ conditions. Natural rock powder of a medium-K tonalite from the Adamello Batholith in Northern Italy served as experimental starting material. Based on compositional data of stable phases in the run products and images of entire run charges, mass balance calculations as well as image processing were performed to investigate the evolution of the crystal/melt ratio with respect to temperature. Furthermore, compositional trends of minerals as well as the liquid line of descent of residual melts were obtained. Orthopyroxene, clinopyroxene and plagioclase were identified as near-liquidus phases (below $990{ }^{\circ} \mathrm{C}$ ). At $900{ }^{\circ} \mathrm{C}$, amphibole joins the solid-phase assemblage at the expense of clinopyroxene, indicating the existence of a peritectic relationship. After an initial near-linear decrease with temperature, residual melt fractions exhibit a plateau of $45-55$ vol. \% between 750 and $850{ }^{\circ} \mathrm{C}$, followed by a rapid decrease coinciding with quartz saturation at $725^{\circ} \mathrm{C}$. Compositions of residual liquids evolve along a typical calc-alkaline differentiation trend with decreasing temperature (increasing $\mathrm{SiO}_{2}$ and decreasing $\mathrm{TiO}_{2}, \mathrm{Al}_{2} \mathrm{O}_{3}, \mathrm{CaO}, \mathrm{MgO}$ and $\mathrm{FeO}$ contents) and become peraluminous below $900{ }^{\circ} \mathrm{C}$. Intermediate to acidic rocks from the Adamello follow the experimental liquid line of descent indicating that the observed compositional spread of the natural intermediate composition rock record can be explained by low-pressure magma differentiation and liquid extraction. Experimentally determined zircon saturation levels are at low temperatures distinctly lower compared to existing and often used Zr-saturation models, but fully consistent with observed and modelled Zr-evolution trends from the natural rock record of the Southern Adamello Batholith inferring that zircon saturation in these intermediate to felsic plutonic rocks occurred at $800-830{ }^{\circ} \mathrm{C}$ corresponding to a melt fraction of about 50 vol. \%.
\end{abstract}

Keywords Arc magmatism · Equilibrium crystallisation · Crystal/melt ratio $\cdot$ Upper crustal plutons · Calc-alkaline intrusion $\cdot$ Tonalite $\cdot$ Adamello $\cdot$ Zircon saturation

Communicated by Mark Ghiorso.

Electronic supplementary material The online version of this article (https://doi.org/10.1007/s00410-019-1619-x) contains supplementary material, which is available to authorized users.

Felix Marxer

felix.marxer@erdw.ethz.ch

1 Institute of Geochemistry and Petrology, ETH Zürich, Clausiusstrasse 25, 8092 Zurich, Switzerland

\section{Introduction}

Calc-alkaline magmatism represents the dominant process of igneous activity at active continental margins. Calc-alkaline rocks are typically rather oxidised and water-bearing and reveal a silica enrichment trend with ongoing differentiation. Because of the characteristic occurrence of calc-alkaline magmatism at active tectonic margins it is intimately related to the generation and evolution of continental crust. New continental crust is typically formed at convergent plate 
margins through intrusion of deeper sourcing magmas into the overlying plate (e.g. Gill 1981; Kay and Kay 1991; Rudnick 1995). Thereby, tonalites and their volcanic equivalents andesites represent by far the most common rock-types (Gill 1981).

To date, a significant amount of experimental studies on intermediate composition tonalites and andesites were conducted at rather high pressures in the range of 0.7-3.0 GPa investigating the petrogenesis of tonalitic/andesitic liquids in the lower crust or even within the mantle wedge (e.g. Green 1972; Wyllie et al. 1976; Alonso-Perez et al. 2009; Nandedkar et al. 2014; Ulmer et al. 2018). Meanwhile, detailed investigation of the late-stage petrologic evolution of tonalitic melts intruding and constituting the upper crust started in the 1970s with few pioneering studies (e.g. Piwinskii 1968, 1973, 1975; Eggler 1972; Eggler and Burnham 1973; Sekine et al. 1979) that, however, lack significant petrological information such as chemical compositions of residual liquids and mineral phases. Therefore, additional experimental constraints are required on the crystallisation behaviour and compositional changes of mineral phases as well as the evolution of the chemical composition of residual melts along the entire liquid line of descent. Piwinskii (1968), (1973) and Piwinskii (1975) presented the sole P-T phase diagrams for various granitoid compositions (tonalitic to granitic) covering the entire temperature range from liquidus to solidus. Contrasting with most other studies, the stability fields of low temperature, lately crystallising phases such as biotite, quartz and alkali-feldspar are explicitly described. Nevertheless, his results are insufficient to explain relevant aspects of the underlying phase equilibria. A major drawback is the lack of any compositional data of crystallising phases (e.g. pyroxene, amphibole or plagioclase) or glasses (corresponding to quenched experimental melts). Furthermore, residual melt fractions were only estimated visually and no information are given regarding relative proportions of individual solid phases. In addition, oxygen fugacity was not consistently controlled for all runs performed, leaving the presented data not without any doubt concerning their suitability to explain in a generalised way the magmatic evolution of tonalitic systems. Numerous studies revealed that oxygen fugacity plays a crucial role in controlling phase relations in calc-alkaline magmatic systems (e.g. Sisson and Grove 1993).

The vast majority of experimental studies on intermediate magmas performed more recently, e.g. Moore and Carmichael (1998), Hammer et al. (2002), Rutherford and Devine (2003), Botcharnikov et al. (2008) or Andújar et al. (2016) investigated considerable temperature ranges $\left(100-150{ }^{\circ} \mathrm{C}\right)$, but concentrated on near-liquidus phase assemblages for a variety of natural andesites in order to determine the origin of phenocrysts in natural rocks and, thus, constrain pre-eruptive magma storage conditions. These studies contributed crucial data on the differentiation of intermediate calc-alkaline magmas at upper crustal conditions, but since major focuses were on investigating near-liquidus phase equilibria their application to the differentiation of upper crustal tonalitic intrusions is limited since no further implications on the course of crystallisation at temperatures distinctively below the liquidus $\left(<850^{\circ} \mathrm{C}\right)$ were established. Martel et al. (1999) conducted detailed investigations at pressures corresponding to upper crustal levels, but mostly concentrated on the influence of elevated $\mathrm{fO}_{2}$ on general phase equilibria. More recently, experimental research, for example by Cottrell et al. (1999), Scaillet and Evans (1999), Costa et al. (2004), Holtz et al. (2005) or Cadoux et al. (2014), focussed on more evolved dacitic systems (e.g. Mt. Pinatubo, Santorini or Mt. Unzen) and provided substantial new data on near-liquidus phase equilibria for these more differentiated rocks. Their results are essential to understand the liquid line of descent of calc-alkaline systems and how silica-rich residual liquids are generated. However, small differences in bulk compositions between dacites and andesites result in distinct differences regarding the stability fields of $\mathrm{Fe}-\mathrm{Mg}-\mathrm{Ca}$ bearing mafic minerals (Cottrell et al. 1999, Cadoux et al. 2014). Thus, comparison of these studies with compositions and stability ranges of mafic phases (amphiboles and pyroxenes) in tonalitic systems is limited and not warranted.

The aim of this study was to investigate the equilibrium crystallisation of a tonalitic system with excess water at lowpressure conditions of $200 \mathrm{MPa}$, corresponding to upper crustal levels (5-6 km depth) from liquidus to near-solidus conditions. In addition to phase proportions, compositions of crystallising minerals and coexisting residual melt were determined to provide insight into the chemical and rheological evolution of intermediate calc-alkaline intrusions in shallow-level magma reservoirs. An auxiliary part of the study concerned the solubility of $\mathrm{Zr}$ in the evolving liquids in order to (1) test existing $\mathrm{Zr}$ solubility models applied to predict the onset of zircon crystallisation in intermediate to felsic magmas and (2) to model the evolution of $\mathrm{Zr}$ concentration and zircon saturation in the granitoids rocks of the Southern Adamello Batholith.

\section{Methods}

\section{Starting materials and capsule design}

For this study, a natural, medium-K tonalite from the Adamello Batholith, the largest Tertiary calc-alkaline intrusion in the Alps, was employed as starting material. Rock powder, originally produced for X-ray fluorescence bulk chemical analysis (XRF), obtained from Verberne (2013), was ground and homogenised in an agate mortar under ethanol together with small amounts of natural zircon powder 
(corresponding to $1500 \mathrm{ppm}$ of zirconium in the final mixture). Table 1 (Electronic Supplementary Material ESM 1) displays the chemical composition of the natural starting material TML (sample 63.1.1) determined by XRF (Verberne 2013). Zirconium was added to test existing zircon saturation models (Watson and Harrison 1983; Boehnke et al. 2013; Gervasoni et al. 2016; Borisov and Aranovich 2019) for their applicability to intermediate to felsic magmatic systems. Experiments were conducted in $\mathrm{Au}_{90} \mathrm{Pd}_{10}$ or $\mathrm{Au}_{100}$ capsules with an outer diameter of $2.3 \mathrm{~mm}$. Capsules were loaded with approximately $20 \mathrm{mg}$ of starting material and specific amounts of deionised $\mathrm{H}_{2} \mathrm{O}$, corresponding to a free water content of $6 \mathrm{wt} \%$ in the final charge to assure water-saturated run conditions. After filling, capsules were carefully sealed by arc welding. Capsules were tested for tightness by either heating them in a furnace at $110{ }^{\circ} \mathrm{C}$ or submerging them in acetone for minimum $1 \mathrm{~h}$. If no weight change was detected after these procedures, capsules were considered tight.

Due to the employment of a natural starting material, chemical disequilibrium in the experimental charges significantly increased in the temperature range of $900-825{ }^{\circ} \mathrm{C}$ (exemplified by the presence of only partly reacted/equilibrated mineral relicts, see "Results" section). Therefore, the standard experimental setup was modified for runs conducted at temperatures $\leq 800{ }^{\circ} \mathrm{C}$ (referred to as "low-temperature runs" throughout the remainder of this manuscript). First, homogenous glasses were pre-synthesised from the natural rock powder by running experiments at $1050{ }^{\circ} \mathrm{C}$ for $12 \mathrm{~h}$ in HCM externally heated pressure vessels at $200 \mathrm{MPa}$ employing $4 \mathrm{~mm} \mathrm{Au}_{90} \mathrm{Pd}_{10}$ capsules containing the $\mathrm{TML}$ starting material plus $6 \mathrm{wt} \%$ of deionised water. After rapid quenching, the fused glass was carefully extracted from the metal capsule and ground in an agate mortar. Few glass fragments were mounted in epoxy resin and checked under a reflected-light microscope and a scanning electron microscope (SEM) for the presence of any crystals. Compositions of the synthesised glasses were determined by electron probe micro-analyser (EPMA) and are reported in Table 1 (renormalised to $100 \mathrm{wt} \%$ on an anhydrous basis). TML_SM1,
TML_SM2 and TML_SM3 correspond to different glass synthesis runs. Comparing the natural rock powder TML with the synthesised glasses reveals that compositions are basically identical. Iron loss to the capsule metal was minor amounting to maximum $11 \%$ relative to the initial value. These glass powders were then subsequently mixed with 2 wt $\%$ of fine-grained natural anorthite $\left(x_{\mathrm{An}}=0.95\right.$, Miyake Jima, Japan, (Amma-Miyasaka and Nakagawa 2002)) and 1 wt $\%$ of kaersutite amphibole (Chain de Puys, France) as seed crystals to enable plagioclase and amphibole to crystallise as sizeable overgrowth rims instead of nucleating widely dispersed in the groundmass. The idea behind this approach is to facilitate the measurement of experimental amphiboles and plagioclases as well as to increase the chance of finding melt pools large enough for analysis. These mixtures were then carefully homogenised in an agate mortar and utilised as starting material for the low-temperature experiments.

In the experiments performed $\leq 775{ }^{\circ} \mathrm{C}$ (FM53, FM54, FM58 and FM70), a layer of fine-grained zircon crystals was added to the tonalitic charge in order to serve as a melt trap (similar to the diamond trap approach established by Hirose and Kushiro (1993)) allowing the formation of melt pools large enough for reliable EPMA analysis. Since zircon saturation was already obtained at $975^{\circ} \mathrm{C}$, the employment of additional natural zircon had no influence on phase equilibria and phase compositions.

\section{Experimental run procedure}

Melting experiments were performed in externally heated HCM pressure vessels at the Institute of Geochemistry and Petrology, ETH Zurich. Argon was utilised as pressure medium and oxygen fugacity was constrained at NNO (nickel-nickel oxide buffer) using methane as a reagent component buffering the hydrogen fugacity of the system and, thus, under water-saturated conditions, oxygen fugacity. The general procedure was to pressurise the vessels with gas at room temperature to about half of the final run pressure. During subsequent heating, gas pressure increased due to thermal expansion to the final target level. Thus, the
Table 1 Major element compositions of experimental starting materials (in wt\%)

\begin{tabular}{lccccccccccc}
\hline Start. mat. & $\mathrm{SiO}_{2}$ & $\mathrm{TiO}_{2}$ & $\mathrm{Cr}_{2} \mathrm{O}_{3}$ & $\mathrm{Al}_{2} \mathrm{O}_{3}$ & $\mathrm{FeO}$ & $\mathrm{MnO}$ & $\mathrm{MgO}$ & $\mathrm{CaO}$ & $\mathrm{Na}_{2} \mathrm{O}$ & $\mathrm{K}_{2} \mathrm{O}$ & $\mathrm{Zr}^{\mathrm{c}}$ \\
\hline TML $^{\mathrm{a}}$ & 60.81 & 0.64 & 0.00 & 17.95 & 5.60 & 0.13 & 3.03 & 7.26 & 2.89 & 1.69 & $1500^{\mathrm{d}}$ \\
TML_SM1 $^{\mathrm{b}}$ & 62.04 & 0.64 & 0.05 & 17.85 & 5.06 & 0.14 & 2.82 & 6.75 & 3.02 & 1.63 & $1394^{\mathrm{e}}$ \\
TML_SM2 $^{\mathrm{b}}$ & 61.87 & 0.64 & 0.01 & 17.72 & 4.99 & 0.14 & 3.01 & 6.88 & 3.09 & 1.66 & $1337^{\mathrm{e}}$ \\
TML_SM3 $^{\mathrm{b}}$ & 61.95 & 0.63 & 0.01 & 17.74 & 5.08 & 0.10 & 2.91 & 6.99 & 2.94 & 1.65 & $1487^{\mathrm{e}}$ \\
\hline
\end{tabular}

${ }^{a}$ Verberne (2013); determined by XRF bulk rock analysis

${ }^{\mathrm{b}}$ Analysed by EPMA and recalculated on an anhydrous base

${ }^{\mathrm{c}} \mathrm{Zr}$ content of starting material in ppm

${ }^{\mathrm{d}} \mathrm{Zr}$ content estimated based on amount of added zircon powder

${ }^{\mathrm{e}} \mathrm{Zr}$ contents measured by LA-ICP-MS 
modification of $\mathrm{pCH}_{4}$ under run conditions was not possible. Consequently, the attainment of desired oxygen fugacity levels was not warranted and Co-Pd redox sensors (Taylor et al. 1992) were utilised to monitor experimental $\mathrm{fO}_{2}$ and assure that desired conditions were attained. We developed a new, modified calibration equation for the $\mathrm{Co}-\mathrm{Pd}-\mathrm{CoO}$ system extending the original equation from Taylor et al. (1992) with a pressure correction term (Pownceby and O'Neill 2000) and a reformulated expression for the Gibbs free energy of the Co-CoO buffer (O'Neill and Pownceby 1993). For more information and formula derivation, see Electronic Supplementary Material ESM 2.

Each experimental run consisted of two separate capsules, one containing the tonalitic charge and another one with the redox sensor assembly. Equilibration temperatures were varied between 700 and $1000{ }^{\circ} \mathrm{C}$ in discrete steps of $25^{\circ} \mathrm{C}$ and monitored with K-type thermocouples. $2 \sigma$ errors on the temperature calibrations for the employed pressure vessels are below $10{ }^{\circ} \mathrm{C}$ and pressure was controlled at $200 \mathrm{MPa}$ with a maximum deviation of $\pm 2 \mathrm{MPa}$. Run durations varied between $24 \mathrm{~h}$ for high-temperature runs $\left(950-1000^{\circ} \mathrm{C}\right)$ and more than $100 \mathrm{~h}$ for experiments at temperatures $\leq 900^{\circ} \mathrm{C}$. Run durations represent a compromise between time required to ensure close approach to chemical equilibrium and minimising hydrogen loss from the argon-methane pressure medium buffering oxygen fugacity in order to maintain constant $\mathrm{fO}_{2}$-conditions during the entire duration of the run. Experiments were quenched by tilting the almost horizontally oriented vessel by $90^{\circ}$ allowing the capsules to fall into the cold end resulting in an instantaneous quench with cooling rates exceeding $100^{\circ} \mathrm{C} / \mathrm{s}$.

Experiments above $800{ }^{\circ} \mathrm{C}$ were directly heated to experimental temperatures and then kept at the equilibration conditions for the entire run duration. For the low-temperature experiments containing the seeded glass starting materials, run protocols deviated: to enhance plagioclase/amphibole crystallisation on the anorthite/kaersutite seeds and dissolve fine-grained plagioclase/amphibole crystals nucleating directly from the starting material glass, temperature cycling was performed in the initial phases of the experiments. For run FM1 8 conducted at $800{ }^{\circ} \mathrm{C}$, the procedure was as follows: the charge was initially heated to $900{ }^{\circ} \mathrm{C}$ and partly molten for $4 \mathrm{~h}$. In a next step, temperature was reduced to $800{ }^{\circ} \mathrm{C}\left(20^{\circ} \mathrm{C} / \mathrm{h}\right.$ cooling rate $)$ and kept $12 \mathrm{~h}$ at this level. Subsequently, temperature was increased again to $850{ }^{\circ} \mathrm{C}$ $\left(25^{\circ} \mathrm{C} / \mathrm{h}\right.$ heating rate) and after a $1 \mathrm{~h}$ dwell time reduced to $800^{\circ} \mathrm{C}$. Finally, after another $12 \mathrm{~h}$ at $800^{\circ} \mathrm{C}$, a last cycle was run to $825^{\circ} \mathrm{C}$. After this procedure, the experiment was kept at the equilibration temperature $\left(800^{\circ} \mathrm{C}\right)$ for $100 \mathrm{~h}$. For the other low-temperature experiments, run protocols were similar, but were adapted individually. Experimental pressure had to be adjusted during this procedure to attain a constant pressure. This, however, had the consequence that partial pressures of methane were constantly modified rendering precise control of oxygen fugacity impossible for these runs.

\section{Sample preparation and analysis}

Recovered experimental capsules were cleaned with ethanol and subsequently weighed to detect possible water loss. Experiments, whose capsules did not reveal any significant weight change were considered successful, mounted in epoxy resin and longitudinal sections through the middle of the capsule were exposed by grinding. Thereafter, run charges were polished with diamond suspensions (finest grade of 1.0 or $0.25 \mu \mathrm{m}$ ) and coated with $20 \mathrm{~nm}$ of carbon for analysis. Specimens were in a first step analysed with a JEOL JSM-6390 scanning electron microscope coupled with a standardised Thermo Fisher NORAN NSS7 Energy Dispersive Spectroscopic system with a 30- $\mathrm{mm}^{2}$ silicon-drift detector (SDD) (SEM-EDS) at the Institute of Geochemistry and Petrology, ETH Zurich. Acceleration voltage for imaging and measurements was set to $15 \mathrm{kV}$. In a second step, major phases (glass, plagioclase, pyroxenes, amphibole and biotite) were analysed with a JEOL-JXA 8200 electron probe micro-analyser (EPMA) at the Institute of Geochemistry and Petrology, ETH Zurich applying an acceleration voltage of $15 \mathrm{kV}$. Pyroxenes and amphiboles were analysed with a beam current of $20 \mathrm{nA}$ and a focussed beam, plagioclases and biotites with a focussed beam and a beam current of $4 \mathrm{nA}$ and residual glasses with a beam diameter of $10 \mu \mathrm{m}$ and a beam current of $2 \mathrm{nA}$. Identical peak and background acquisition times were employed. $\mathrm{Na}$ and $\mathrm{K}$ were always analysed first to minimise alkali migration. Measurement times for sodium were $10 \mathrm{~s}$ for glasses and plagioclases and $15 \mathrm{~s}$ for pyroxenes and amphiboles. Potassium was always measured for $15 \mathrm{~s}$ and measurement times for all other elements varied between 20 and $40 \mathrm{~s}$, depending on the particular analysis setup. Raw data were corrected with the PRZ algorithm (Goldstein et al. 1981).

$\mathrm{Zr}$ contents of experimental glasses were measured with a ASI Resolution $193 \mathrm{~nm}$ ArF excimer laser equipped with a Laurin Technic 155 constant geometry 2-volume ablation cell coupled to a Thermo Element XR sector-field ICP-MS at the Institute of Geochemistry and Petrology, ETH Zurich. The laser repetition rate was $5 \mathrm{~Hz}$ and the laser energy was about $80 \mathrm{~mJ}$. Background and ablation signal were measured with an acquisition time of $30 \mathrm{~s}$ each. Helium with a current flow of $0.5 \mathrm{l} / \mathrm{min}$ served as cell gas to transport the plasma into the mass spectrometer. A laser spot size of $13 \mu \mathrm{m}$ was chosen to allow analyses of small melt-spots. The standard reference material NIST 610 served as primary external standard and the material GSD-1G, was used as secondary standard to ensure quality control of measurements. These external standards were measured distributed over the entire laser ablation series to correct for any time drift effect of 
the mass spectrometer. Raw data were processed using the MATLAB program SILLS (Guillong et al. 2008), where $\mathrm{CaO}$ (in wt\%, measured by EPMA) served as internal standard to quantify the ablation signals.

\section{Results}

All experiments consisted of residual melt quenched to a homogeneous glass and variable proportions of mineral phases. The persistent occurrence of vapour bubbles confirms that experiments were performed under fluid-saturated conditions. Identified mineral phases are plagioclase (plag), orthopyroxene (opx), clinopyroxene (cpx), amphibole (amph), apatite (ap), ilmenite (ilm), magnetite (mt), ulvospinel (ulvsp), biotite (bt), quartz (qtz) and zircon (zr). An overview of the experiments including run conditions, mineral assemblages and phase proportions is given in Table 2 (Electronic Supplementary Material ESM 3) and average compositions of major phases measured by EPMA are reported in Table 3 (Electronic Supplementary Material ESM 4). Minor phases (ap, ilm, mt, ulvsp and zr) were identified by SEM-EDS since chemical compositions could not be determined by EPMA due to small grain sizes $(<5 \mu \mathrm{m})$. Oxygen fugacities calculated from Co-Pd redox sensor compositions varied around $\mathrm{NNO} \pm 0.5$ implying that aimed experimental $\mathrm{fO}_{2}$ conditions were obtained. Figure $1 \mathrm{a}, \mathrm{b}$ illustrates the typical appearance of run products performed either on the natural rock powder starting material (Fig. 1a) or on the seeded pre-synthesised glass powders (Fig. 1b).

\section{Run appearances}

Experimental run products are characterised by a homogeneous appearance with a uniform spatial distribution of mineral phases. Orthopyroxenes crystallised as distinct idiomorphic needles, whereas clinopyroxene grains are of rather isometric shapes. In runs conducted with the powdered natural rock, amphibole crystals typically consist of a relic core of natural amphibole (showing cleavage and turbid

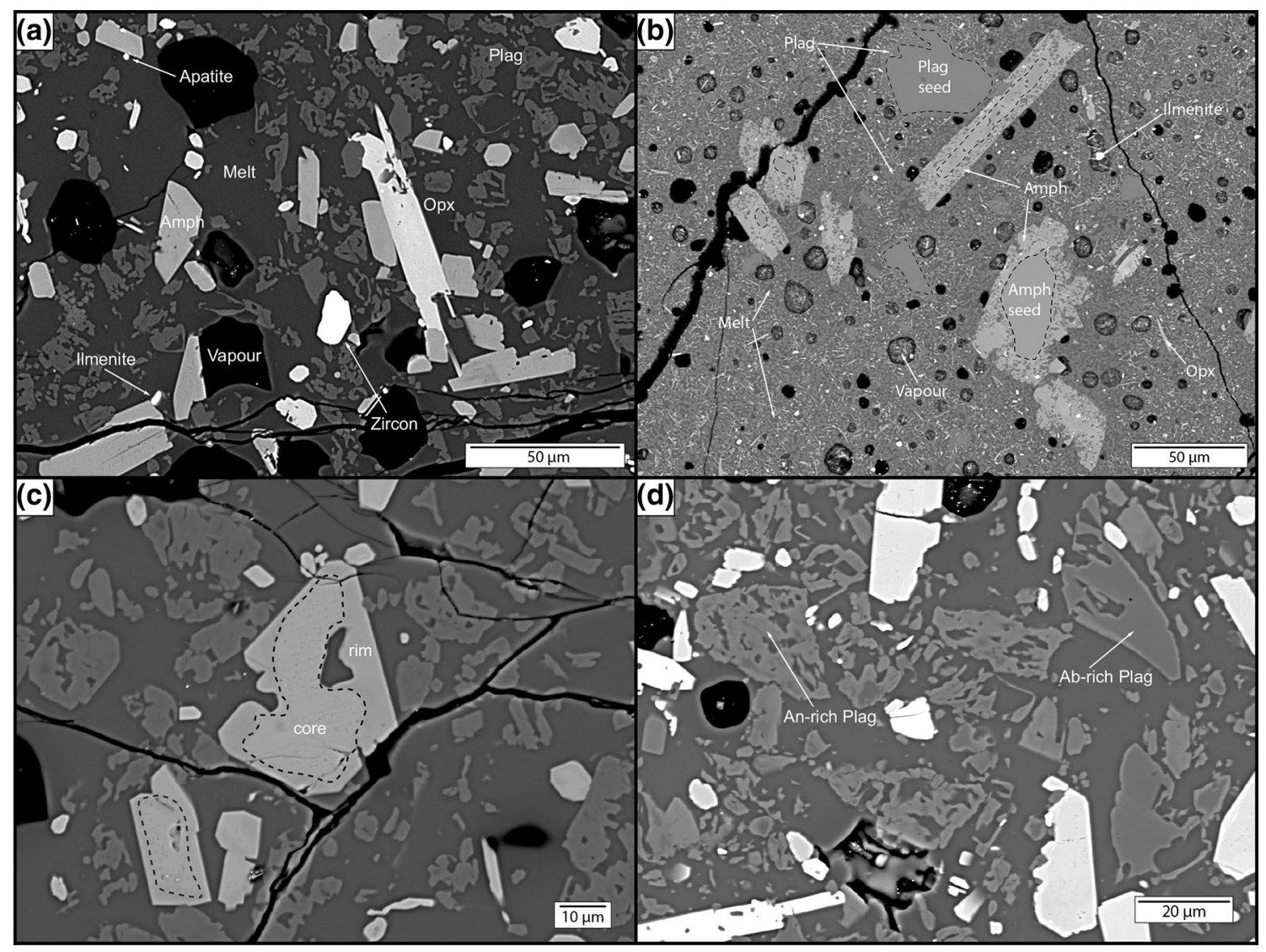

Fig. 1 BSE images of experimental run products a Typical run appearance of high-temperature experiments (FM10-875 ${ }^{\circ} \mathrm{C}$ ) employing the natural starting material. b Typical run appearance of low-temperature experiments (FM53-775 ${ }^{\circ} \mathrm{C}$ ) with indicated kaersutite/anorthite seeds and overgrowth rims. c Amphibole crystals with core/rim zonation in experiments performed on the natural rock powder $\left(825-900{ }^{\circ} \mathrm{C}\right)$. d Morphology and patchy appearance of plagioclases in runs performed on natural rock powder at intermediate temperatures $\left(825-875^{\circ} \mathrm{C}\right)$ 
surfaces) and overgrowth rims of amphibole in equilibrium with the residual melts (Fig. 1c). Depending on experimental temperatures, thicknesses of the crystallised rims varied, with larger rims at higher temperatures. Beside the large grains, smaller, newly grown, amphibole crystals were found dispersed in the groundmass of the experimental charges whose compositions are identical with the overgrowth rims. In the experiments where kaersutite seeds were used, equilibrium amphibole overgrowth rims amounted to 5-15 $\mu \mathrm{m}$ (Fig. 1b). The common presence of melt inclusions indicates that rims crystallised relatively fast. Kaersutite seed crystals do not exhibit crystal morphology due to mechanical damage during starting material preparation and occasionally show weak resorption related to the temperature cycling procedure. The effect of partial dissolution of seed crystals on the bulk system composition was assumed to be minor, thus having no influence on phase equilibria and compositions of crystallising minerals. Weak zonation of amphibole seed overgrowth rims was identified sporadically in the experiments at 750,725 and $700{ }^{\circ} \mathrm{C}$ and attributed to temperature cycling. Compositions of the outermost zones are interpreted to represent equilibrium, while inner zones formed at higher temperature plateaus. Additionally, very fine-grained intergrowth of hornblende with cummingtonitic/actinolitic amphibole was recognised in these lowtemperature runs. Reliable chemical compositions of these phases could not be obtained due to their very fine-grained nature. Magmatic cummingtonite has previously been described in several studies on differentiated plutonic (e.g. Callegari 1966; De Capitani and Liborio 1990) and volcanic systems (e.g. Ewart et al. 1975; Smith and Leeman 1982; Shane et al. 2005). Geschwind and Rutherford (1992) investigated experimentally the stability of cummingtonite in the Mount St. Helens dacite and concluded that cummingtonite substitutes for orthopyroxene at temperatures below $790{ }^{\circ} \mathrm{C}$ leading to the mafic phase assemblage cummingtonite and hornblende. Furthermore, Evans and Ghiorso (1995) and Ghiorso et al. (1995) studied the thermodynamics of cummingtonite in the system $\mathrm{FeO}-\mathrm{MgO}-\mathrm{SiO}_{2}-\mathrm{H}_{2} \mathrm{O}$ and concluded that at $\mathrm{fO}_{2}$ conditions close to $\mathrm{NNO}$ and a pressure of $200 \mathrm{MPa}$, orthopyroxene coexists with cummingtonite over a small temperature window (ca. $760-740{ }^{\circ} \mathrm{C}$ ), before being completely replaced by amphibole. In contrast, in our experiments, orthopyroxene, cummingtonite and hornblende appear to coexist over a considerably wider temperature range $\left(775-725^{\circ} \mathrm{C}\right)$. This difference is most likely related to the more complex bulk system of our tonalitic composition (additional components compared to FMSH and more mafic than a dacite), leading to an expansion of the coexistence field of ferromagnesian silicates.

At high temperatures (above $875{ }^{\circ} \mathrm{C}$ ), plagioclase crystals are of small sizes with homogeneous compositions and hypidiomorphic shapes while at intermediate temperatures $\left(825-875^{\circ} \mathrm{C}\right)$ grain morphologies become complex with visible resorption phenomena and heterogeneities in chemical compositions, expressed as patchy arranged zones of various grey scales in a BSE image for one single plagioclase grain (Fig. 1d). Brighter zones, predominantly present in the outer parts or rims of plagioclase crystals were interpreted to be in equilibrium with the residual melts while the darker and, thus, more albitic cores or zones were inferred to represent decomposing relic plagioclases from the powdered natural rock. Distinction of these two zones based on chemical compositions was not straightforward since it was not persistently possible to identify two populations of plagioclase compositions but rather a range between two endmembers. Additionally, plagioclase crystals with higher anorthite contents than equilibrium rims $\left(x_{\mathrm{An}}>0.9\right)$ were found in some experiments and are interpreted to represent residual cores of natural strongly zoned plagioclases, typically found in these tonalitic rocks (e.g. Blundy and Sparks 1992). In runs conducted with the seeded glass starting material $\left(\leq 800{ }^{\circ} \mathrm{C}\right)$, plagioclase formed (1) very fine-grained lathshaped crystals dispersed in the melt and (2) overgrowth rims on the anorthite seeds $(5-10 \mu \mathrm{m}$ in extent, Fig. 1b). Biotite crystallised as small platelets, while quartz crystals are of hypidiomorphic, isometric shape. Ilmenite formed very small needle-like crystals of less than $10 \mu \mathrm{m}$ length finely dispersed in the groundmass. In some run charges, ilmenite aggregates composed of small individual crystals were found in addition and interpreted to be related to the replacement of natural biotite grains and re-crystallisation of the iron and titanium components as ilmenite during the experiments. Magnetite identified at $900{ }^{\circ} \mathrm{C}$ (FM9) crystallised euhedrally along the capsule walls but was not found as single crystals within the groundmass, while at $700{ }^{\circ} \mathrm{C}$ magnetite forms small isometric crystals. Ulvospinel grains in the 850 and $825^{\circ} \mathrm{C}$ runs are of xenomorphic shape resembling skeletal crystals which we interpret to result from to the replacement of partly resorbed natural magnetite grains. Apatite grains were commonly rather large and of xenomorphic shapes and, thus, represent partly dissolved apatite crystals from the natural starting material. Zircons appear as small xenomorphic grains finely dispersed in the experimental charges and correspond to non-dissolved zircons added to the starting material indicating that zircon saturation was reached.

\section{Phase assemblage and phase proportions}

Phase proportions were calculated employing the nonweighted, least-squares regression algorithm implemented in Microsoft Office EXCEL based on EPMA/SEM-EDS analyses of the residual melts and coexisting minerals as well as the bulk rock composition of the starting material. Mineral phases which were only present in trace amounts 
were discarded for the regression procedure to improve fitting quality and to minimise uncertainties on calculated phase proportions. For ilmenite and magnetite, compositions determined by SEM-EDS were employed for calculations since their small grain sizes made reliable analysis by EPMA impossible. For runs where plagioclase and amphibole crystals exhibited a core/rim zonation, average plagioclase and amphibole compositions were calculated from individual rim and core analyses. Relative proportions of rims (and cores) were estimated based on BSE images. The presence of mineral cores was tested for its influence on mass balance calculations and no significant impact on the resulting proportions was found. For charges lacking an Fe-Ti-oxide phase, nominal iron loss was calculated by treating the iron alloying with the capsule metal as an additional phase with a composition of $100 \mathrm{wt} \% \mathrm{FeO}$. Fe-loss to the capsule walls was established to be below $16.5 \%$ with respect to the initial iron content of the starting material. For the low-temperature experiments $\left(700-800^{\circ} \mathrm{C}\right)$ that were performed on the presynthesised glasses, minimum values of iron loss can be established by calculating the amount of $\mathrm{FeO}$ lost to the capsule walls during starting material glass synthesis at $1050{ }^{\circ} \mathrm{C}$. Comparing the composition of the initial starting material TML with EPMA analyses of the recovered glasses yields relative Fe-losses between 9.3 and $10.8 \%$. We imply that final Fe-losses of the low-T runs were not much higher than these initial values since iron alloying with capsule walls is distinctly reduced at low-temperature conditions (Ratajeski and Sisson 1999; Barr and Grove 2010) and some of these experiments were additionally performed using pure Au capsules $\left(700-775{ }^{\circ} \mathrm{C}\right)$. Standard errors on calculated phase proportions are provided in Table 2 and result maximum values of about $1.5 \mathrm{wt} \%$ for plagioclase and residual melt and $3.5 \mathrm{wt} \%$ for the mafic phases. Phase proportions of experimental runs between 850 and $700{ }^{\circ} \mathrm{C}$ were additionally established by image processing employing BSE images of the entire charges and the software ImageJ and results agree well with calculated proportions derived by mass balance regression. However, it has to be emphasised that image processing only provides estimates as area fractions have to be converted to volume fractions (and mass fractions). Additionally, analysis of the low-temperature runs was rather challenging due to the very fine-grained morphology of the charges.

Calculated modal phase proportions (in wt\%) are illustrated in Fig. 2. It should be noted that this bar diagram does not strictly reflect stability ranges of crystallising phases since mass balance calculations were simplified ignoring accessory phases such as apatite or a mafic mineral phase being only present in trace amounts, indicating that experimental conditions were close to the mineral's stability limits. Reported specific fractions of mafic minerals (cpx, opx and amph) are not considered to be fully quantitative, but rather have to be treated with care, especially since calculation procedures have shown that the regression is quite sensitive to small changes in mafic mineral compositions resulting in overestimation of the proportion of one specific mafic phase at the expense of the other coexisting ones.

The liquidus of the investigated composition was identified slightly below $990{ }^{\circ} \mathrm{C}$. At $975^{\circ} \mathrm{C}$, orthopyroxene, clinopyroxene and plagioclase are stable and represent near-liquidus phases. Residual melt fractions decrease nearly linearly with decreasing temperature from 1000 to $875^{\circ} \mathrm{C}$, accompanied by a continuous increase in plagioclase contents. In the temperature range $850-750{ }^{\circ} \mathrm{C}$ a plateau of $50-40 \mathrm{wt} \%$ residual melt is present. Pyroxene fractions display a constant increase to $925^{\circ} \mathrm{C}$, and diminish abruptly between 925 and $900{ }^{\circ} \mathrm{C}$, where a significant decrease in opx contents and the disappearance of cpx coincide with the occurrence of amphibole joining the solid-phase assemblage, indicating a peritectic relationship, where amphibole is produced by the reaction of pyroxenes with residual liquid. No clear trend regarding modal proportions is evident for amphibole and orthopyroxene between 900 and $725^{\circ} \mathrm{C}$. Amph contents vary between 7 and $17 \mathrm{wt} \%$ and opx from 4 to $9 \mathrm{wt} \%$. This behaviour is interpreted to result from the inability of the linear regression algorithm to distinguish properly between mafic phases and is not related to any changes in phase equilibria. Ilmenite starts crystallising at $900{ }^{\circ} \mathrm{C}$ together with apatite and, overall, shows a continuous increase in modal abundance with decreasing temperature. Due to some iron loss to the noble metal capsules, ilmenite contents are probably slightly overestimated, especially at higher temperatures, where Fe-loss is expected to be more prominent. Magnetite or ulvospinel was present in the experiments at 900 (FM9), 850 (FM11), 825 (FM12) and $700{ }^{\circ} \mathrm{C}$ (FM70). The inconsistent stability of spinel can be related to small variations in experimental $\mathrm{fO}_{2}$ due to imperfect control of oxygen fugacity in the employed pressure vessels. Biotite starts to crystallise between 775 and $750{ }^{\circ} \mathrm{C}$ with phase proportions increasing to $10 \mathrm{wt} \%$ at $700{ }^{\circ} \mathrm{C}$. Orthopyroxene disappears between 725 and $700{ }^{\circ} \mathrm{C}$, while quartz saturation is reached at $725^{\circ} \mathrm{C}$. The crystallisation of quartz (and biotite) in the two lowest temperature experiments results in a rapid decrease of residual melt fractions from nearly 40 wt $\%$ at $750{ }^{\circ} \mathrm{C}$ to $12 \mathrm{wt} \%$ at $700{ }^{\circ} \mathrm{C}$. Zircon was present in all experiments below $975{ }^{\circ} \mathrm{C}$, but is absent at 990 and $1000{ }^{\circ} \mathrm{C}$.

\section{Approach to equilibrium}

Based on the following observations, we assume that chemical equilibrium between crystallised minerals and coexisting residual melts was approached in our experiments: (1) run durations of up to $247 \mathrm{~h}$ (low-T runs) seem to be sufficient to reach near-equilibrium conditions. (2) Observed mineral phases as well as residual melts result homogeneous 


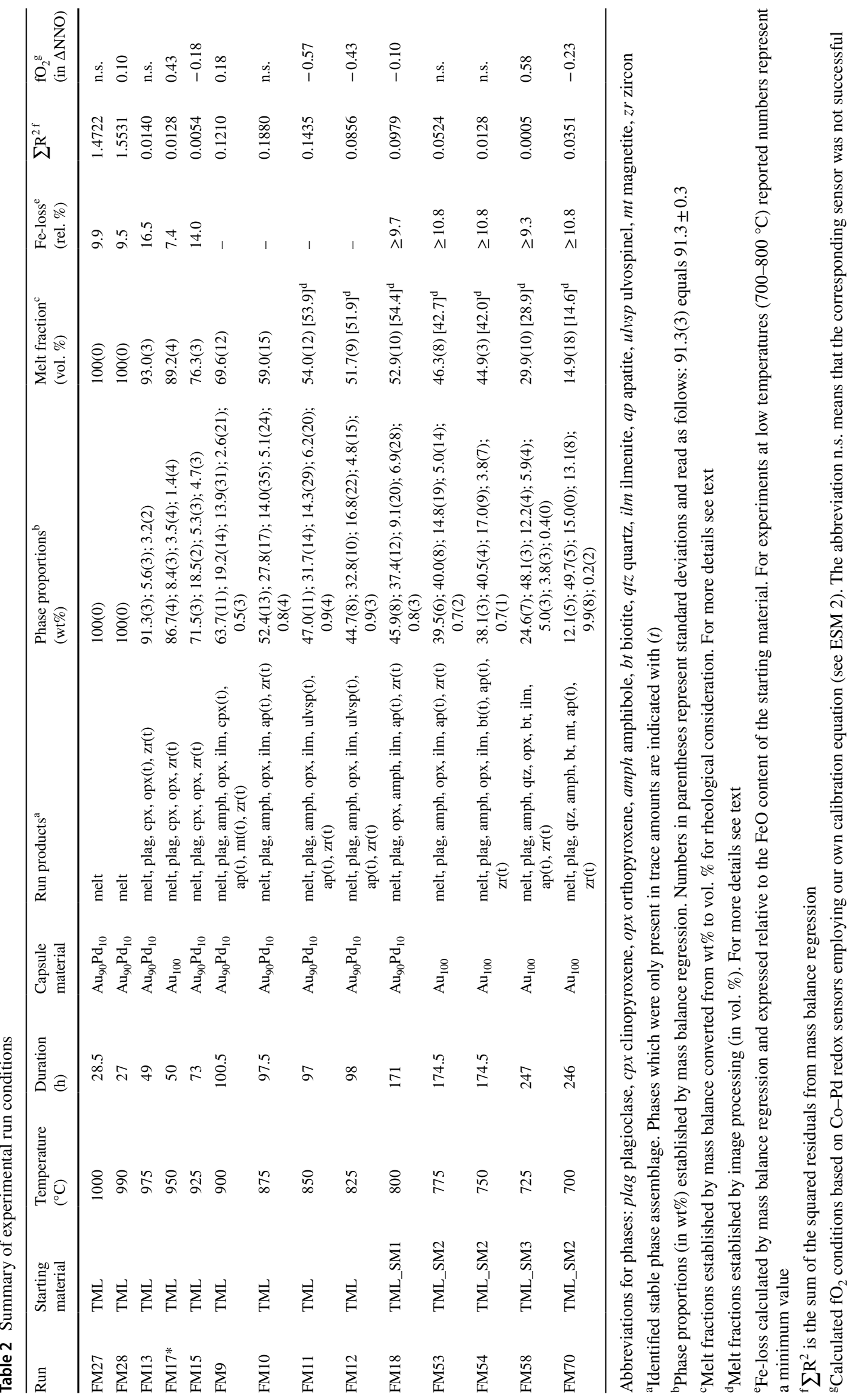


Fig. 2 Modal phase proportions (in wt\%) of experimental runs obtained by mass balance calculations. For abbreviations of mineral names, see Table 2

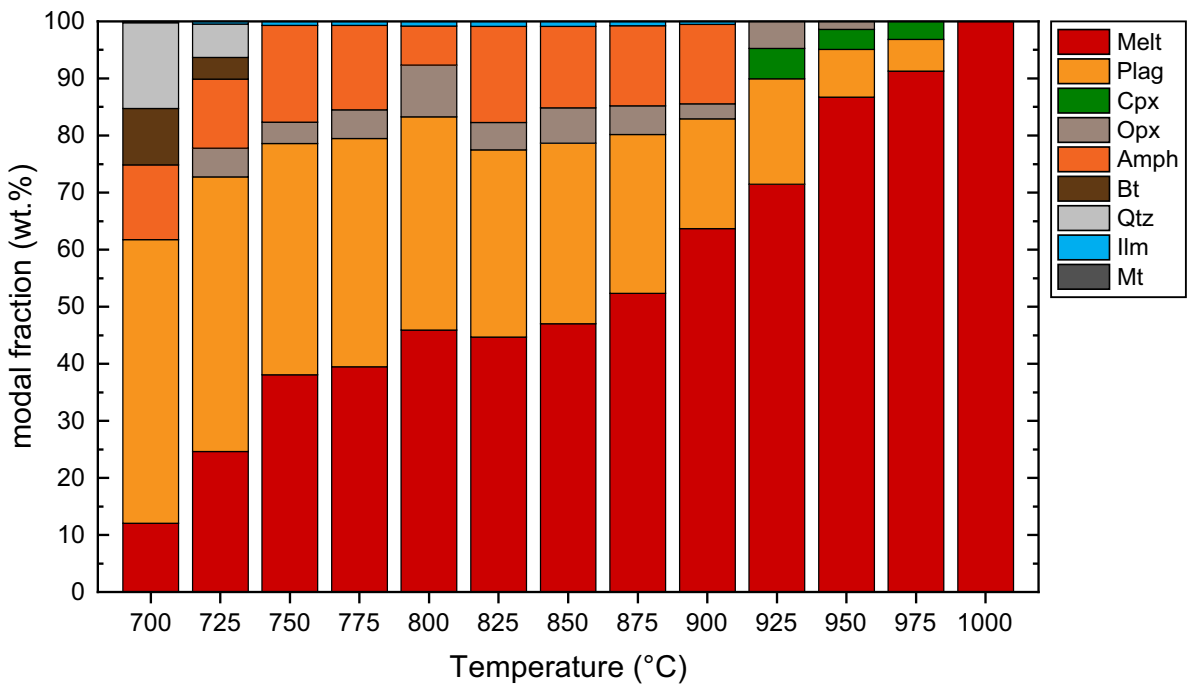

compositions throughout entire capsule sections and phase compositions are homogenous within analytical uncertainty. (3) Residual melts and minerals exhibit consistent chemical evolution trends with ongoing differentiation. (4) In all experiments, sufficient melt phase was present (>12 wt\%) to ensure chemical interaction of crystallising phases. The occasional presence of relic crystal cores originating from the natural rock powders (amphiboles and albite-rich plagioclase zones) indicates that in some experiments on the natural rock powder only local equilibrium (Pichavant et al. 2007) was achieved. However, based on the consistent compositional mineral trends, we assume that the presence of some relic cores exerts negligible influence on the overall phase equilibria observed in the experimental charges. This issue of only partly reacted starting material components was avoided for the lowest-T runs using a pre-synthesised glass, but due to the sluggish kinetics in highly evolved magmatic systems (Piwinskii and Martin 1970; Johannes 1980; Scaillet et al. 1995) complete attainment of chemical equilibrium cannot be warranted for these experiments. Temperature cycling did not have a major influence on general phase equilibria, since mineral disequilibrium growth could only be identified as minor zonation of overgrowth rims on amphibole seed crystals in experiments at 750,725 and $700{ }^{\circ} \mathrm{C}$, where the compositions of inner zones can be linked to previous cycling temperatures (compositions of these zones match roughly experimental amphiboles stable in runs at higher temperatures). (5) Consistent $\mathrm{Ca}-\mathrm{Na}$ exchange distribution coefficients $\left(K_{\mathrm{D}}^{\mathrm{Ca} / \mathrm{Na}}\right)$ between plagioclases and residual melts are an additional important criterion to test experimental run products for the attainment of equilibrium (Grove et al. 2003). The fitting procedure for the exchange $K_{\mathrm{D}}^{\mathrm{Ca} / \mathrm{Na}}$ between plagioclase analyses and residual melt yielded a value of $5.84 \pm 0.34$ for the temperature range $800-975^{\circ} \mathrm{C}$ and 2.05 from 775 to $700{ }^{\circ} \mathrm{C}$ (Fig. 3). The
Ca-Na $K_{\mathrm{D}}$ established for $800-975{ }^{\circ} \mathrm{C}$ perfectly agrees with an exchange $K_{\mathrm{D}}^{\mathrm{Ca} / \mathrm{Na}}$ of $\sim 5.5$ for a basalt at water-saturated conditions and a pressure of $200 \mathrm{MPa}$ observed by Sisson and Grove (1993). However, several other studies performed on more evolved bulk compositions (e.g. Martel et al. 1999; Scaillet and Evans 1999; Costa et al. 2004) report variable $K_{\mathrm{D}}^{\mathrm{Ca} / \mathrm{Na} \text {, }}$ between 1.8 and 4.8 indicating that other parameters (such as bulk system and/or liquid composition) additionally influence the partitioning of $\mathrm{CaO}$ and $\mathrm{Na}_{2} \mathrm{O}$ between plagioclase and residual melt. However, with increasing differentiation towards high-silica rhyolites, the $\mathrm{Ca}-\mathrm{Na} \mathrm{K}_{\mathrm{D}}$ diminishes significantly to a value around $2.05 \pm 0.30$. The same behaviour was observed by Ulmer et al. (2018) in their fractional crystallisation experiments on hydrous arc magmas, where $K_{\mathrm{D}}^{\mathrm{Ca} / \mathrm{Na}}$ 's varied from 4.4 to 5.0 at temperatures higher than $800{ }^{\circ} \mathrm{C}$ but decrease to $1.8-2.2$ between 720 and $800{ }^{\circ} \mathrm{C}$.

Calculated $\mathrm{Fe}-\mathrm{Mg}$ exchange coefficients $\left(K_{\mathrm{D}}^{\mathrm{Fe} / \mathrm{Mg}}\right)$ between amphiboles and pyroxenes and residual liquids are consistent at experimental temperatures above $825{ }^{\circ} \mathrm{C}$. At lower temperatures, $\mathrm{Fe}-\mathrm{Mg}$ exchange $K_{\mathrm{D}}$ 's could not be fitted for amphibole and orthopyroxene due to high analytical uncertainties on $(\mathrm{Fe} / \mathrm{Mg})^{\text {melt }}$ ratios. Observed mean $K_{\mathrm{D}}^{\mathrm{Fe} / \mathrm{Mg} \text { 's }}$ of orthopyroxene of $0.322 \pm 0.017$ and clinopyroxene of $0.180 \pm 0.059$ deviate from previously published values for a slightly more mafic $\mathrm{Mg}$-andesite system of 0.24 for opx and cpx (Grove et al. 2003). Likewise, Martel et al. (1999) reported $\mathrm{Fe}-\mathrm{Mg}$ exchange coefficients of 0.26-0.27 for orthopyroxene and 0.25 for clinopyroxene. Calculated $\mathrm{Fe}-\mathrm{Mg} K_{\mathrm{D}}$ 's for clinopyroxene for Andújar et al. (2016) and Cadoux et al. (2014) vary between 0.18 and 0.26 and, thus, partly overlap with our data. Our exchange coefficient for amphiboles $(0.243 \pm 0.021)$ is significantly lower than the value of 0.32 established by Grove et al. (2003), the range from 0.30 to 0.38 identified by Sisson and Grove (1993) 
Fig. 3 Molar $(\mathrm{Ca} / \mathrm{Na})$ ratio of equilibrium plagioclases vs. coexisting residual melts. $\mathrm{Ca}-$ Na exchange coefficients $\left(K_{\mathrm{D}}\right)$ were established by weighted linear fitting of data points. Experimental equilibration temperatures are additionally indicated. If error bars for individual data points are not shown, they are smaller than the corresponding symbol

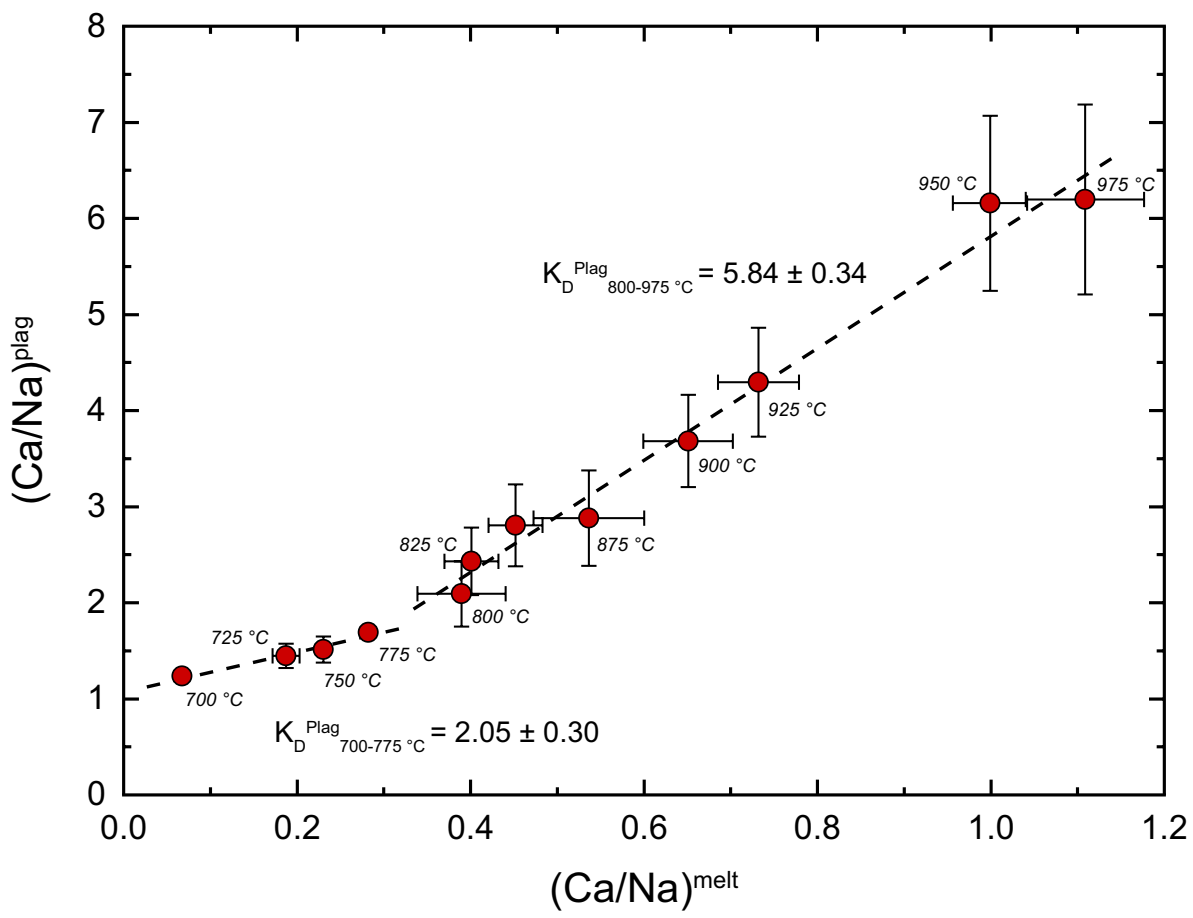

and values between 0.35 and 0.40 observed by Martel et al. (1999) for moderately oxidising conditions. However, it roughly agrees with calculated values for synthesised amphiboles by Scaillet and Evans (1999), Costa et al. (2004) and Cadoux et al. (2014), which scatter between 0.08 and 0.39 . Deviations of $\mathrm{Fe}-\mathrm{Mg} \mathrm{K} \mathrm{D}_{\mathrm{D}}$ 's of this study from literature values are interpreted to be related to variations in studied bulk system compositions and $\mathrm{fO}_{2}$ conditions as all studies report $\mathrm{Fe}-\mathrm{Mg}$ exchange coefficients based on ferrous iron only.

In summary, the internal consistency of established mineral-melt exchange coefficients for $\mathrm{Ca}-\mathrm{Na}$ and $\mathrm{Fe}-\mathrm{Mg}$ at high temperatures $\left(825-1000{ }^{\circ} \mathrm{C}\right)$ points towards attainment of phase equilibria in the performed experiments. At low temperatures $\left(700-800{ }^{\circ} \mathrm{C}\right)$ the situation is less clear since the $K_{\mathrm{D}}^{\mathrm{Ca} / \mathrm{Na}}$ for plagioclase decreases to a lower value, although this behaviour has already been observed by previous studies.

\section{Compositions of major phases}

\section{Residual liquids}

Except for the lowest temperature experiments, melt pools were sufficiently large to enable representative EPMA analyses that did not suffer from extensive diffusional Na-loss during measurements. Even with the employment of zircon melt traps, residual melt-spots were rather small in experiments FM18, FM53 and FM54 limiting the quality of the liquid analyses to some extent. Therefore, melt compositions at 800,775 and $750{ }^{\circ} \mathrm{C}$ exhibit some scatter resulting in slight deviations from the generally smooth evolution trends for some oxide components (e.g. $\mathrm{TiO}_{2}, \mathrm{MgO}$ or $\mathrm{K}_{2} \mathrm{O}$ ). Figure 4 illustrates the compositional evolution of residual liquids with decreasing temperature.

With progressive differentiation, controlled by the crystallisation of mineral phases, experimental liquids become continuously enriched in silica (Fig. 4a). Likewise, $\mathrm{Al}_{2} \mathrm{O}_{3}$, $\mathrm{MgO}$ and $\mathrm{CaO}$ exhibit a uniform decrease with decreasing temperature (Fig. 4c, e, f), consistent with the progressive crystallisation of mafic minerals (pyroxenes and/or amphibole) together with relatively anorthite-rich plagioclase. $\mathrm{TiO}_{2}$ (Fig. 4b) exhibits an initial increase followed by a continuous decline at temperatures below $925{ }^{\circ} \mathrm{C}$ coinciding with the stabilisation of an Fe-Ti-oxide phase (ilmenite) between 925 and $900{ }^{\circ} \mathrm{C}$ being responsible for the sharp bend of the trend. Note that stability fields of Fe-Ti-oxide phases strongly depend on $\mathrm{fO}_{2}$ conditions and that our experiments were relatively reducing (predominance of ilmenite as oxide phase). The relative position of the $\mathrm{TiO}_{2}$ bend could, therefore, change with more oxidising or reducing conditions occurring at higher and lower temperatures, respectively. Fluctuations of $\mathrm{FeO}_{\text {tot }}$ contents of the liquids at highest temperatures $\left(975-925^{\circ} \mathrm{C}\right.$ ) are related to variable extent of iron loss to the capsule walls and are followed by a continuous decrease at temperatures $\leq 900{ }^{\circ} \mathrm{C}$ (Fig. 4 d). $\mathrm{K}_{2} \mathrm{O}$ reveals a continuous enrichment with ongoing differentiation down to $700{ }^{\circ} \mathrm{C}$ illustrating its incompatible behaviour in the studied magmatic system (Fig. 4h) with the exception of the last three experiments where biotite is stable and the curve flattens. The evolution pattern of sodium does 
Fig. 4 Major and minor oxide concentrations (in wt\%) of residual melts as a function of temperature. The green square denotes the natural starting material (TML). In case error bars are not shown, they are smaller than the symbol size. Black dashed line in panel $\mathrm{f}$ corresponds to an exponential fit $\left(\mathrm{T}\left({ }^{\circ} \mathrm{C}\right)=(-411.7 \pm 33.0)\right.$ $* \exp [-\mathrm{CaO} /(4.35 \pm 0.79)]+$ $(1061.3 \pm 39.4))$ that was used to calculate extraction temperatures of natural Adamello granitoids
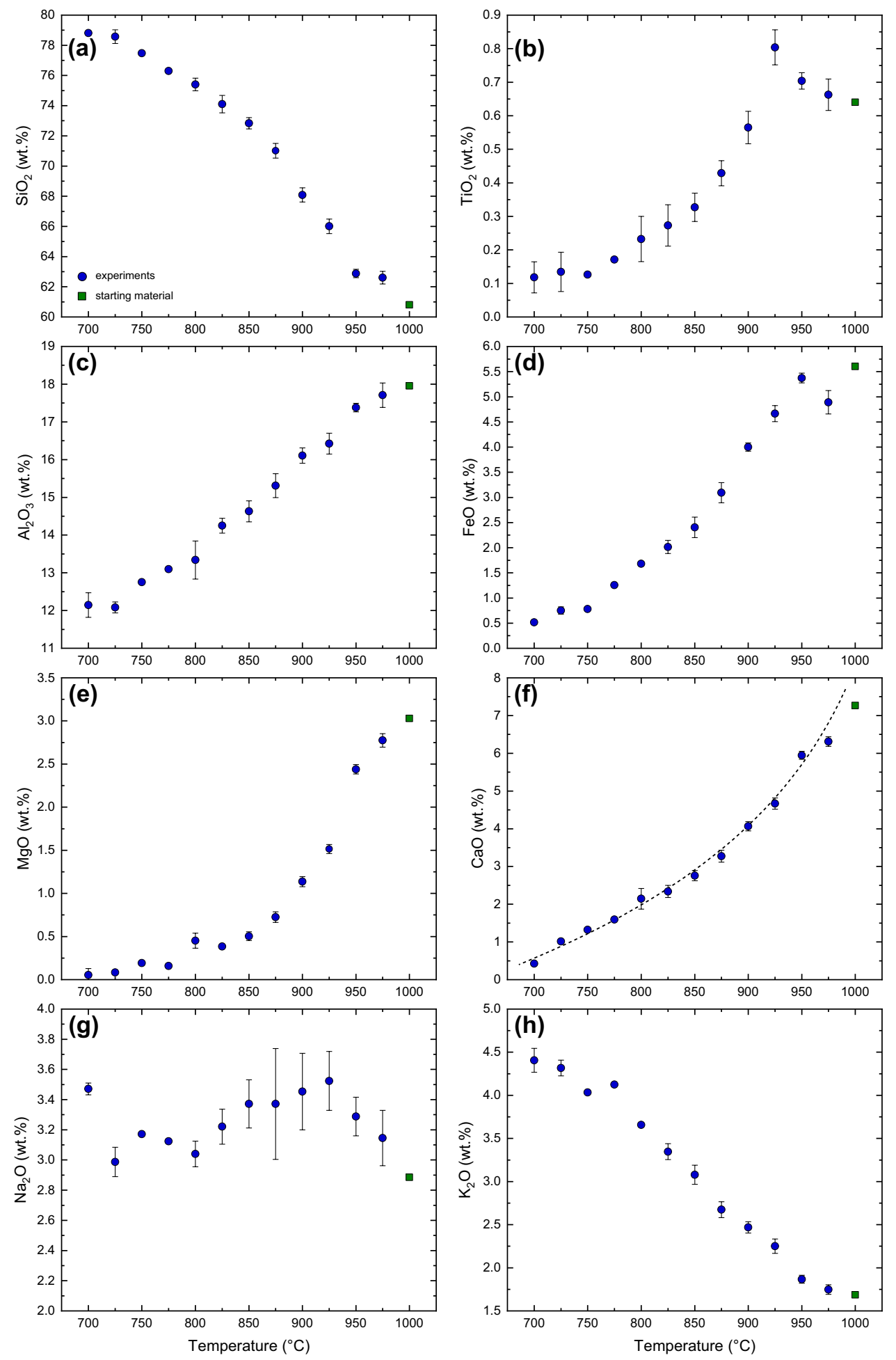

not exhibit a simple trend but is characterised by an initial increase to $900{ }^{\circ} \mathrm{C}$ followed by an irregular decrease (Fig. 4g). The bend at $900-925{ }^{\circ} \mathrm{C}$ is most likely related to the combination of the stabilisation of an albite-rich component in the crystallising plagioclase and to a minor extent to the co-precipitation of Na-bearing amphibole, depleting the residual melt continuously in $\mathrm{Na}_{2} \mathrm{O}$, consistent with the evolution of experimental plagioclase compositions towards lower anorthite contents with decreasing temperature. The observed final increase from 725 to $700{ }^{\circ} \mathrm{C}$ results from the precipitation of quartz leading to a re-enrichment of sodium in the remaining liquid. All derivative liquids in this study 
are quartz-normative. In terms of alumina saturation, it is, however, worth noting that with decreasing temperature, residual melts evolve from metaluminous to slightly peraluminous compositions between 925 and $900{ }^{\circ} \mathrm{C}$ (Fig. 5), i.e. they become corundum normative. The molar alumina saturation index $\left(\mathrm{ASI}=\mathrm{Al}_{2} \mathrm{O}_{3} /\left(\mathrm{CaO}+\mathrm{Na}_{2} \mathrm{O}+\mathrm{K}_{2} \mathrm{O}\right)\right)$ of residual liquids ranges between 0.91 (starting material) and 1.08 (run FM70 at $700{ }^{\circ} \mathrm{C}$ ).

Zirconium contents of pre-synthesised starting materials and experiments spanning the temperature range 800-1000 ${ }^{\circ} \mathrm{C}$ were measured by LA-ICP-MS and are reported in Tables 1 and 3 and plotted in Fig. 6. The synthesised starting material glasses as well as the runs above zircon saturation, which was reached around $975-950{ }^{\circ} \mathrm{C}$, show a homogeneous bulk Zr-composition between 1340 and $1490 \mathrm{ppm}$ (illustrated by the grey bar). At lower temperatures, melt zirconium contents exhibit an exponential decrease to $100 \mathrm{ppm}$ at $800{ }^{\circ} \mathrm{C}$. No attempts were made to measure residual glasses in the experiments at lower temperatures, since (1) glass pockets were too small for the laser beam and (2) the presence of the zircon melt trap would have resulted in strongly contaminated ablation signals. The consistent decrease of $\mathrm{Zr}$-melt contents with temperature indicates close approach to equilibrium in terms of zircon saturation. Melt Zr contents were obtained through (partial) dissolution of natural zircon crystals added at a concentration level of $1500 \mathrm{ppm}$ in the experiments from 975 to $825^{\circ} \mathrm{C}$ that occurred sufficiently fast with respect to run durations. Approach to equilibrium is further supported by the experiment at $800{ }^{\circ} \mathrm{C}$ which was conducted

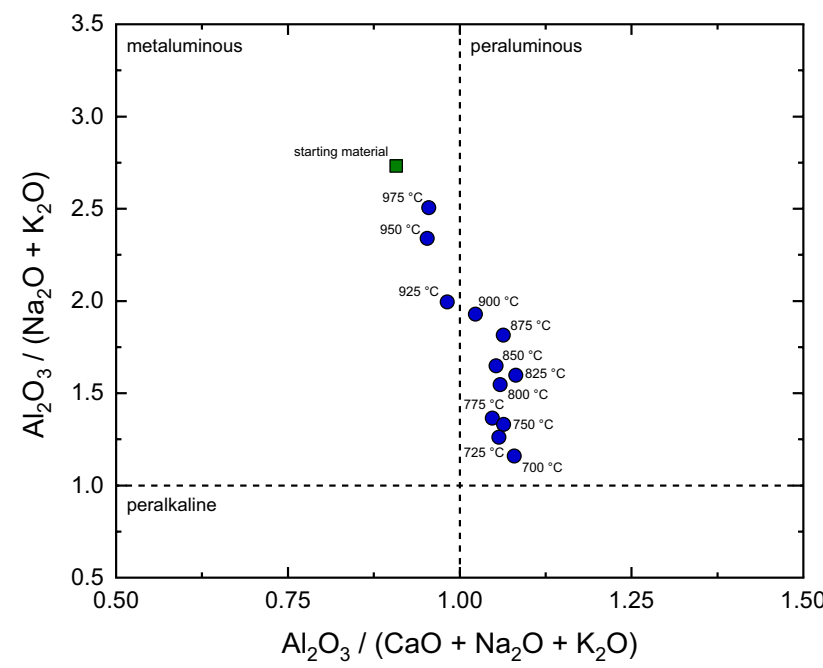

Fig. 5 Residual melt compositions plotted in the alumina saturation versus peralkalinity index diagram (ratios calculated on a molar base). Experimental liquids evolve from metaluminous to peraluminous with decreasing temperature. The green square represents the bulk tonalitic starting material composition (TML) and the blue dots correspond to experimental liquids with pre-synthesised starting material glass (containing approx. $1500 \mathrm{ppm}$ of $\mathrm{Zr}$ ) that was free of any relic zircon crystals. Measured Zr-melt contents that were established in this case by crystallisation of zircon from a strongly zircon oversaturated melt perfectly align with the systematic trend obtained from the zircon dissolution experiments at higher temperature. This would not be expected if diffusion would inhibit close approach to equilibrium as this should result in underestimation of melt $\mathrm{Zr}$ contents in the dissolution experiments $\left(975-825^{\circ} \mathrm{C}\right)$ and overestimation of the $\mathrm{Zr}$ content at $800{ }^{\circ} \mathrm{C}$ in the zircon crystallisation experiment.

\section{Pyroxenes}

Pyroxene compositions were recalculated into molar proportions of pyroxene endmembers: enstatite $\left(\mathrm{Mg}_{2} \mathrm{Si}_{2} \mathrm{O}_{6}\right.$, En), ferrosilite $\left(\mathrm{Fe}_{2} \mathrm{Si}_{2} \mathrm{O}_{6}, \mathrm{Fs}\right)$ and wollastonite $\left(\mathrm{Ca}_{2} \mathrm{Si}_{2} \mathrm{O}_{6}\right.$, Wo) and are plotted in the pyroxene quadrilateral in Fig. 7. Additional pyroxene endmembers such as $\mathrm{CaAl}_{2} \mathrm{SiO}_{6}$ (Ca-Tschermak pyroxene) or $\mathrm{Na}$ - and Ti-bearing endmembers were ignored due to their minor abundance (0.003-0.030). Calcium was, thus, entirely assigned to the wollastonite component. Low-Ca orthopyroxene compositions define a continuous trend with decreasing temperatures towards lower $x_{\mathrm{Mg}}$ values (from 0.77 to 0.50 ). This trend is in agreement with the liquid line of descent of the residual liquids with a relative increase of the $\mathrm{FeO} / \mathrm{MgO}$ ratio with ongoing differentiation. Only orthopyroxenes formed at $800{ }^{\circ} \mathrm{C}$ are faintly off this general evolution since they exhibit a slightly higher enstatite component than the ones stable at $825^{\circ} \mathrm{C}$ pointing towards a slightly more enhanced Fe-loss in the $800{ }^{\circ} \mathrm{C}$ experiment. The starting material used for the $800{ }^{\circ} \mathrm{C}$ run (TML_SM1) has lost $10 \%$ of its initial $\mathrm{FeO}$ during synthesis. Unfortunately, we could not calculate the iron loss in the $825^{\circ} \mathrm{C}$ charge due to the presence of Fe-Ti-oxides, but supposedly it is distinctly lower than $10 \%$ because of the rather low run temperature. Alternatively, it has been shown by Speidel and Osborn (1967) and Martel et al. (1999) that under rather oxidising conditions $\mathrm{FeO} / \mathrm{MgO}$ ratios of pyroxenes (and amphiboles) are lower than under moderately to slightly reducing conditions due to the stabilisation of $\mathrm{Fe}^{3+}$ in the melt and consequently lower amounts of ferrous iron available for mineral formation. Therefore, a significantly higher $\mathrm{fO}_{2}$ in run $\mathrm{FM} 18$ at $800{ }^{\circ} \mathrm{C}$ compared to FM12 at $825^{\circ} \mathrm{C}$ could as well explain the observed inversion of the general Fe-Mg orthopyroxene trend. However, it is questionable if the rather small difference in $\mathrm{fO}_{2}$ based on Co-Pd redox sensors of 0.3 log units between the two runs is sufficient to explain the inversion of the $\mathrm{x}_{\mathrm{Mg}}$. Wollastonite components of orthopyroxenes vary between 2 and $5 \%$ with no clear trend discernible with decreasing temperature. The reported orthopyroxene composition at 


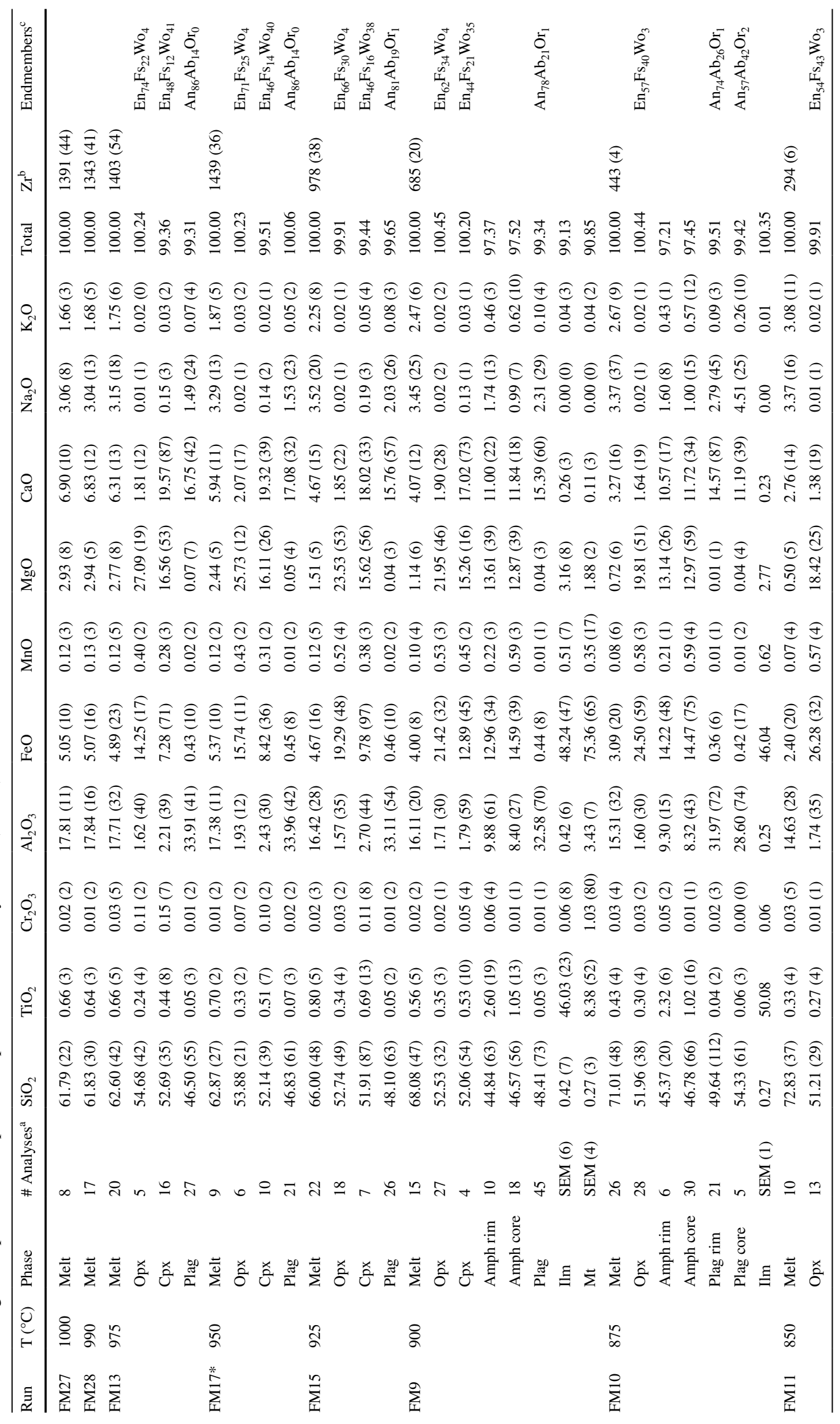




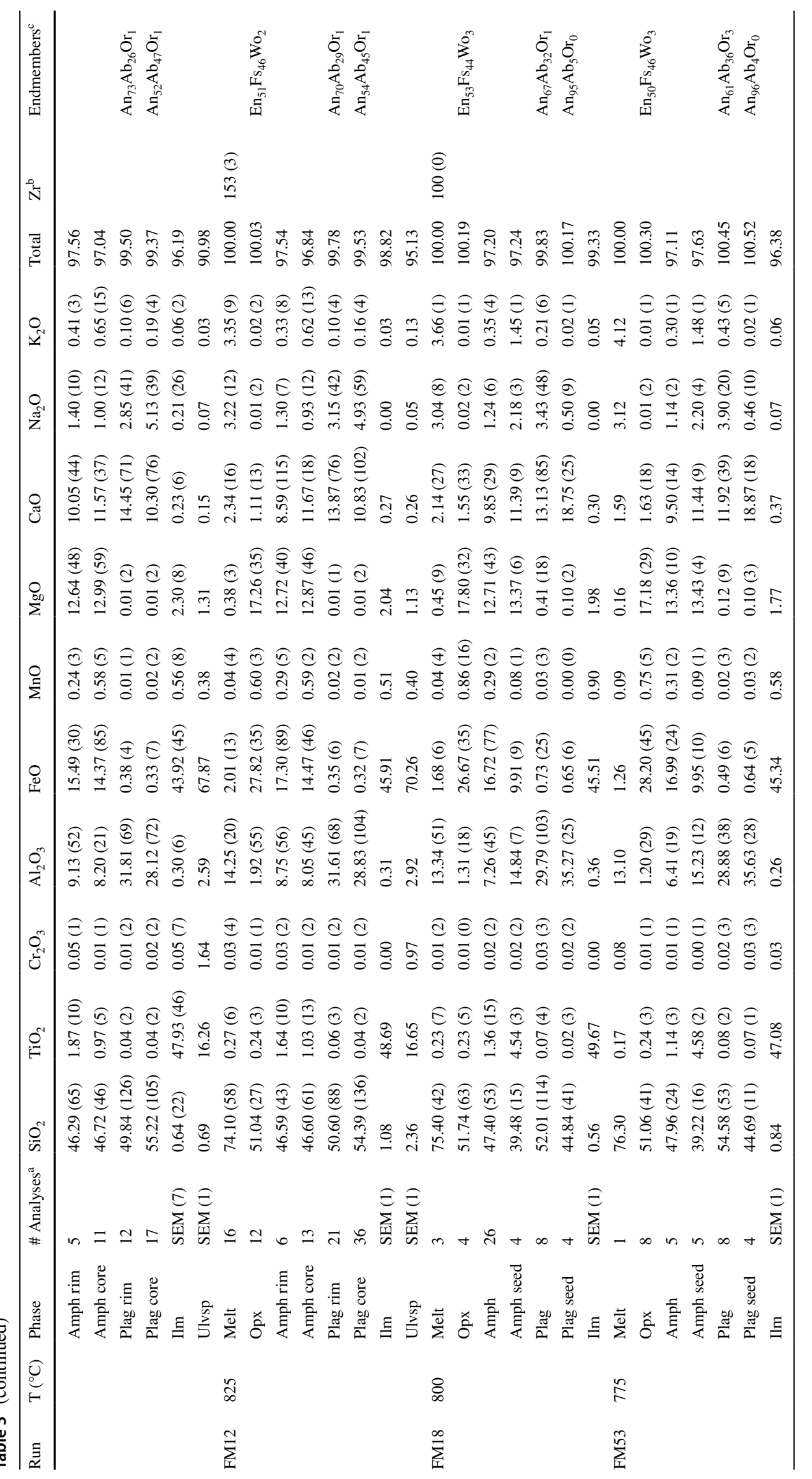




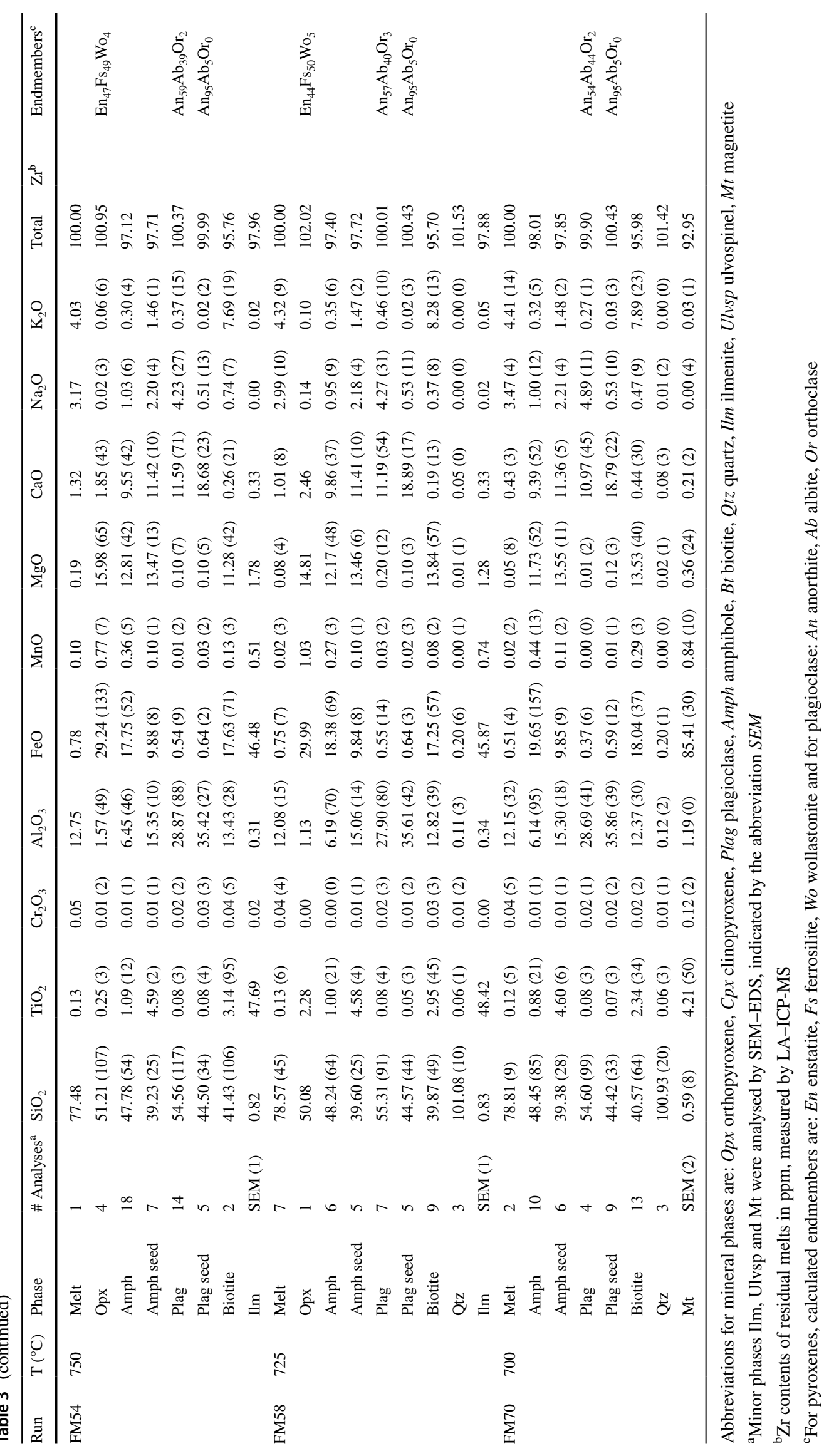




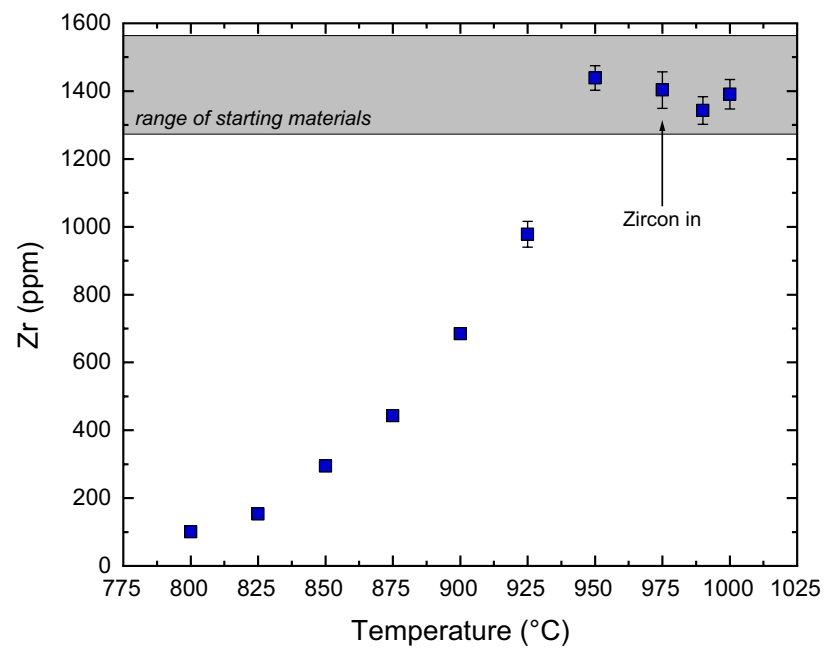

Fig. 6 Zirconium contents of experimental liquids (in ppm) measured by LA-ICP-MS. The grey shaded bar represents the range in bulk $\mathrm{Zr}$ concentrations of employed starting materials. Zircon crystallisation was first observed at $975{ }^{\circ} \mathrm{C}$ resulting in an exponential decrease of $\mathrm{Zr}$ contents of glasses from 950 to $800{ }^{\circ} \mathrm{C}$. In case error bars are not shown, they are smaller than the symbol size

$725{ }^{\circ} \mathrm{C}$ was most probably contaminated during measurement by unnoticed $\mathrm{Fe}$-Ti-oxide inclusions explaining its high $\mathrm{TiO}_{2}$ content of $2.28 \mathrm{wt} \%$.

Clinopyroxene compositions fall in the augite compositional field and define a distinct trend towards lower Wo (0.41-0.35) and higher Fs contents (0.12-0.21) with decreasing temperature together with an only limited decrease in the enstatite component. In general, calcium contents of clinopyroxenes are controlled by both temperature and iron content (Lindsley 1983). In the present case, were clinopyroxene always coexists with orthopyroxene, a decrease in temperature results in increasing Ca-contents controlled by the topology of the Opx-Cpx solvus. In contrast, Fe-enrichment at constant temperature causes a shrinkage of the solvus and thus decreasing Ca-contents. Consequently, clinopyroxene compositional trends of our experiments are predominantly controlled by $\mathrm{Fe}$-enrichment resulting in the observed decrease of their Ca-contents.

\section{Amphiboles}

Equilibrium amphiboles stable in successful experiments (rims as well as relic cores) are of $\mathrm{Mg}$-hornblende composition. Amphibole analyses were recalculated using the amphibole normalisation algorithm RAMP (Spear and Kimball 1984) with an empirically fixed $\mathrm{Fe}^{3+} / \mathrm{Fe}_{\text {tot }}$ ratio of 0.20 compromising between a value of 0.31 determined by Mössbauer spectroscopy on compositionally very similar natural amphiboles from the adjacent, coeval Bergell tonalite pluton (Reusser 1987) and a value of approximately 0.12 obtained by Clowe et al. (1988) in an experimental study on $\mathrm{Mg}$-hornblende equilibrated at $650{ }^{\circ} \mathrm{C}, 100 \mathrm{MPa}$ and $\mathrm{fO}_{2}$ conditions corresponding to the $\mathrm{Ni}-\mathrm{NiO}(\mathrm{NNO})$ and fayalite-magnetite-quartz (FMQ) equilibria. Figure 8 illustrates the evolution of selected compositional parameters for experimental amphiboles with ongoing differentiation. Beside equilibrium amphiboles (red symbols), crystal cores (black symbols) identified in the experiments from 825 to $900{ }^{\circ} \mathrm{C}$ were additionally plotted. Grey shaded areas indicate compositional ranges covered by natural, zoned amphiboles from an adjacent, compositionally identical tonalite (Blumone tonalite, data taken from Bole (2012)). Cores are basically invariant in terms of composition among the different charges and overlap with natural amphibole compositions confirming that they represent relic fragments of natural hornblendes originating from the starting material. With decreasing temperature, silica contents increase continuously from 6.6 at $900{ }^{\circ} \mathrm{C}$ to 7.1 atoms per formula unit (a.p.f.u.) at $700{ }^{\circ} \mathrm{C}$ (Fig. 8a). Concomitantly, Al concentrations decrease from 1.7 to 1.1 a.p.f.u., principally related to decreasing tetrahedral aluminium $\left(\mathrm{Al}^{\mathrm{IV}}\right)$ from 1.44 to 0.87 a.p.f.u., while $\mathrm{Al}^{\mathrm{VI}}$ contents show no clear trend varying in the range $0.17-0.34$ a.p.f.u. $\mathrm{The}^{2}{ }^{2}-\mathrm{Mg}^{2+}$ exchange vector (Fig. 8b) is negatively correlated with temperature ranging
Fig. 7 Compositions of experimental pyroxenes plotted in the pyroxene endmember quadrilateral. Low-Ca orthopyroxene compositions are represented by red and high-Ca clinopyroxenes by blue dots. Labels close to symbols denote experimental equilibration temperatures

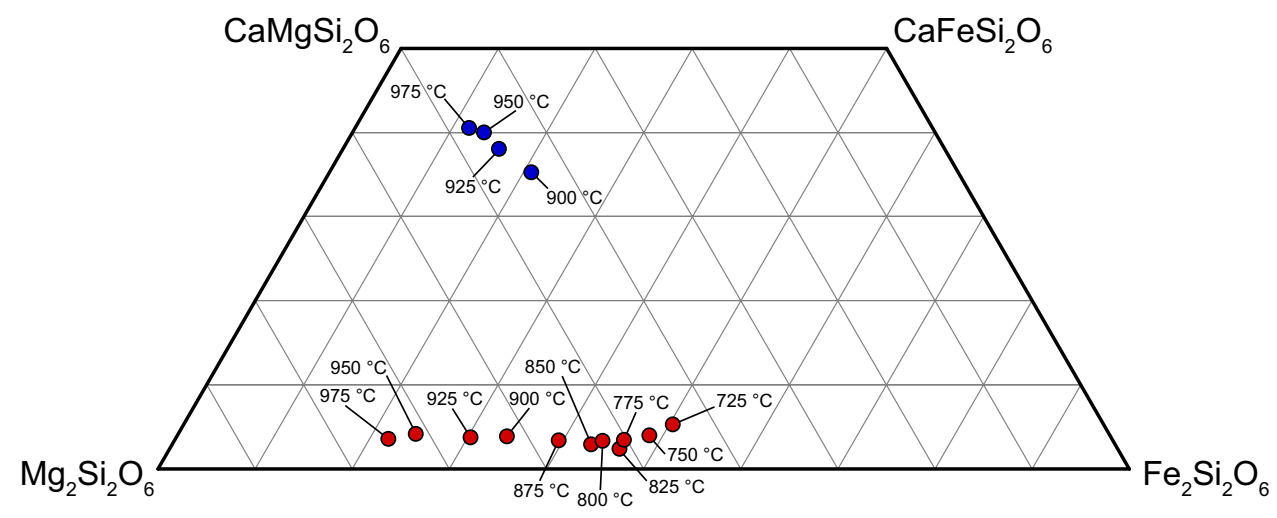



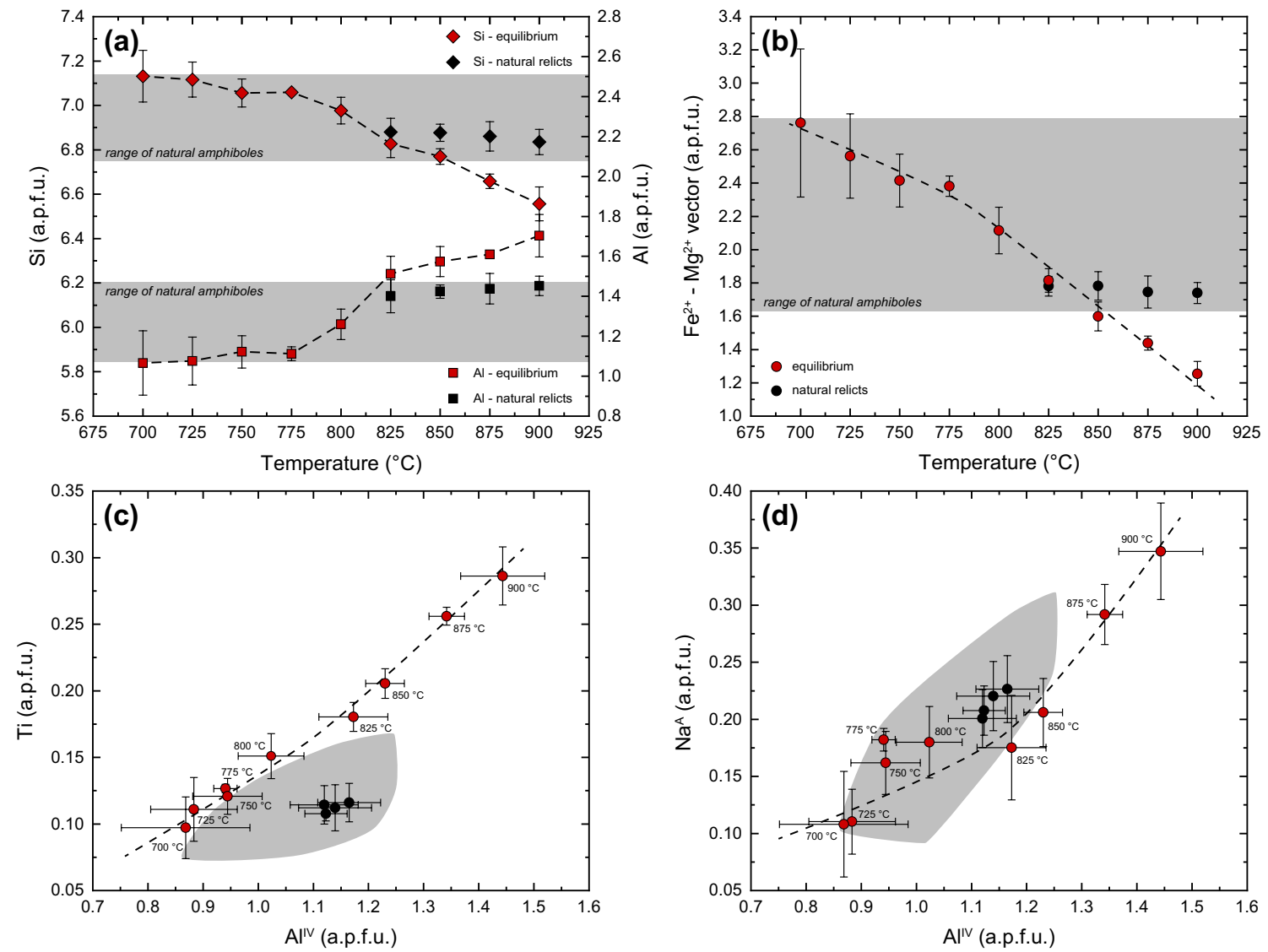

Fig. 8 Compositional trends of experimental amphiboles (equilibrium rims and natural relicts, in a.p.f.u.): $\mathbf{a} \mathrm{Si}$ and $\mathrm{Al}$ vs. temperature; b $\mathrm{Fe}^{2+}-\mathrm{Mg}^{2+}$ vector vs. temperature; c titanium vs. tetrahedral aluminium $\mathrm{Al}^{\mathrm{IV}}$ and $\mathbf{d}$ sodium contents on the A-site vs. $\mathrm{Al}^{\mathrm{IV}}$. Red dots represent amphibole rims in equilibrium with the residual melt while

from 1.25 at $900{ }^{\circ} \mathrm{C}$ to 2.76 a.p.f.u. at $700^{\circ} \mathrm{C}$. Likewise, $x_{\mathrm{Mg}}$ (calculated with $\mathrm{FeO}_{\text {tot }}$ ) of amphiboles decrease regularly from 0.65 to 0.52 with progressing differentiation. Ti concentrations decline consistently with decreasing $\mathrm{Al}^{\mathrm{IV}}$ (and temperature) from 0.29 to 0.10 a.p.f.u. (see Fig. 8c) implying that the extent of the Ti-Tschermaks vector diminishes with decreasing temperature. The slope of $\sim 3$ for Ti vs. $\mathrm{Al}^{\mathrm{IV}}$ infers that $\mathrm{Al}^{\mathrm{IV}}$ is about 1:1 controlled by regular and Ti-Tschermak's exchange reactions. Sodium contents on the A-site $\left(\mathrm{Na}^{\mathrm{A}}\right)$ exhibit a distinct positive correlation with tetrahedral aluminium from 0.11 to 0.35 a.p.f.u. (Fig. 8d) illustrating the well-known effect of temperature on the edenite exchange vector (e.g. Holland and Blundy 1994). With the exception of Ti-contents (Fig. 8c), the compositions of the natural, zoned amphiboles match well the experimental data corresponding to temperatures of $850-700{ }^{\circ} \mathrm{C}$ reflecting continuous growth of amphibole along the liquid line of descent. The slightly higher Ti-contents of the experimental amphiboles is related to an enhanced titanium activity in the experimental charges due to slightly lower experimental $\mathrm{fO}_{2}$

black ones correspond to amphibole cores found in the experiments on the natural rock powder $\left(825-900{ }^{\circ} \mathrm{C}\right)$ corresponding to relicts from the starting material. Grey shaded areas indicate compositional ranges covered by natural, zoned amphiboles from the Blumone tonalite (data from Bole (2012))

conditions with respect to the natural case (for more details, see "Discussion" section). Crystallisation temperatures of experimental amphiboles were calculated using the richterite-edenite thermometer by Holland and Blundy (1994) to verify attainment of equilibrium. Resulting temperatures deviate $6-43{ }^{\circ} \mathrm{C}$ from effective run temperatures and, thus, lie within reported algorithm uncertainties of $35-40{ }^{\circ} \mathrm{C}$. Only for amphibole stable at $700{ }^{\circ} \mathrm{C}$ the calculated temperature is with $766{ }^{\circ} \mathrm{C}$ distinctly too high. An increase in the mismatch with decreasing temperature can be related to the increasing iron contents of amphiboles (19.65 wt\% at $700{ }^{\circ} \mathrm{C}$ ) leading to higher uncertainties on recalculated ferric iron concentrations. Since quartz is coexisting with amphibole in this run, calculation was repeated employing the edenite-tremolite thermometer by Holland and Blundy (1994) yielding $732^{\circ} \mathrm{C}$, perfectly agreeing within error with the equilibration temperature. In addition, we applied the models of Ridolfi et al. (2010) and Ridolfi and Renzulli (2012) to calculate crystallisation temperatures and pressures for our experimental amphiboles. Results from 900 to 
$850^{\circ} \mathrm{C}$ agree within error with the experimental run conditions, while amphibole compositions from 825 to $700{ }^{\circ} \mathrm{C}$ result distinctly lower pressures (around $100 \mathrm{MPa}$ ) and highly variable temperatures. It has to be noted that the algorithms from Ridolfi and Renzulli (2012) perform slightly better in reproducing the experimental conditions, while Ridolfi et al. (2010) result error messages for the experimental amphiboles stable at $825,775,750$ and $700{ }^{\circ} \mathrm{C}$.

\section{Plagioclases}

Anorthite contents of plagioclases are based on the molar proportions of the feldspar endmembers recalculated from EPMA analyses. Figure 9 shows average anorthite contents $\left(x_{\mathrm{An}}\right)$ of plagioclases in equilibrium with residual melt (red dots) as well as relic, more albite-rich zones found in experiments between 825 and $875^{\circ} \mathrm{C}$ (black dots). Anorthite contents of crystal rims of natural plagioclases from the Blumone tonalite (Bole 2012) are indicated by the grey shaded area. Due to the rather high compositional variability of newly grown experimental plagioclase crystals, errors on average compositions are relatively high. Nevertheless, a clear trend of continuously decreasing anorthite contents of experimental plagioclases with decreasing temperature from about 0.85 at $975^{\circ} \mathrm{C}$ to 0.54 at $700{ }^{\circ} \mathrm{C}$ is discernible. Potassium contents exhibit a similar variability with an overall increase with decreasing temperature from 0.04 to $0.10 \mathrm{wt} \%$ at $975-925{ }^{\circ} \mathrm{C}$ to $0.27-0.46 \mathrm{wt} \%$ at $775-700{ }^{\circ} \mathrm{C}$. Compositions of relic plagioclase zones vary slightly among different runs $\left(x_{\mathrm{An}}=0.53-0.58\right)$, but show no distinct trend with temperature. Anorthite contents of natural plagioclase rims are restricted to the lowest compositional range covered by the

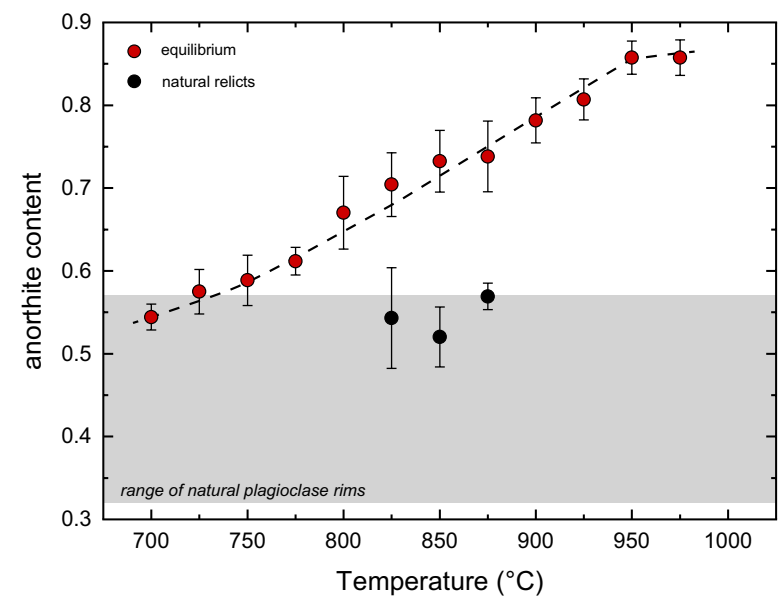

Fig. 9 Anorthite contents of experimental plagioclases. Red points represent equilibrium compositions, while black ones correspond to natural relicts found in the experiments at $825-875^{\circ} \mathrm{C}$. Grey shaded bar shows compositional range covered by crystal rims of natural plagioclases from the Blumone tonalite (data from Bole (2012)) experiments and the natural relicts and extend to considerably lower values indicating that the rims of natural plagioclases mostly crystallised close to and at the solidus in the granite minimum (that was not reached in the experiments).

\section{Discussion}

Before discussing our results in detail, we emphasise that our experiments were all conducted under water-saturated conditions (although the presence of minor $\mathrm{CO}_{2}$ in the bulk system cannot be excluded). Several studies (e.g. Gardner et al. 1995; Lowenstern 2001) showed that intermediate arc magmas are not implicitly $\mathrm{H}_{2} \mathrm{O}$-saturated when they reach shallow levels but additionally contain significant amounts of $\mathrm{CO}_{2}$ (leading to a diminished activity of water due to the presence of a mixed fluid phase). Phase equilibria of water-undersaturated magmas can differ significantly when compared to saturated ones. Therefore, crystallisation of $\mathrm{H}_{2} \mathrm{O}-\mathrm{CO}_{2}$ bearing andesites or dacites represents another possible magmatic process driving residual liquids towards highly differentiated compositions (e.g. Martel et al. 1999) that are not discussed here.

\section{Comparison with previous studies}

At $200 \mathrm{MPa}$, liquidus temperatures for water-saturated tonalitic/andesitic systems were established multiple times around $1000{ }^{\circ} \mathrm{C}$ (Eggler 1972; Eggler and Burnham 1973; Piwinskii 1973; Martel et al. 1999; Hammer et al. 2002; Botcharnikov et al. 2008; Andújar et al. 2016), in agreement with our experimental findings. Reported near-liquidus phase assemblages (melt + plag $+\mathrm{cpx}+\mathrm{opx})$ coincide with this study although exact crystallisation sequences and phase saturation temperatures differ significantly. This is related to the high sensitivity of the stability fields of mafic minerals on bulk system compositions and, thus, on small chemical variations between different starting materials utilised in the various studies. In particular, the onset of amphibole crystallisation is rather variable. Moore and Carmichael (1998) as well as Piwinskii (1973) reported amphibole as a near-liquidus phase while Eggler (1972), Eggler and Burnham (1973), Martel et al. (1999), Hammer et al. (2002), Rutherford and Devine (2003), Botcharnikov et al. (2008) and Andújar et al. (2016) observed amphibole appearance at considerably lower temperatures (around $900{ }^{\circ} \mathrm{C}$ ). Only at pressures distinctly higher than $200 \mathrm{MPa}$, amphibole becomes a liquidus phase in intermediate magmatic systems (e.g. Allen et al. 1975; Alonso-Perez et al. 2009). A possible explanation for the early amphibole saturation in the experiments of Moore and Carmichael (1998) could be the significantly higher $\mathrm{fO}_{2}$ conditions of their runs (around $\mathrm{NNO}+2$ ), since Martel et al. (1999) pointed out that at $200 \mathrm{MPa}$ under 
water-saturation, highly oxidising conditions $(\mathrm{NNO}+2$ to $\mathrm{NNO}+3$ ) enhance the thermal stability of amphibole by up to $60{ }^{\circ} \mathrm{C}$ compared to moderate oxygen fugacity due to the increased availability and the preferred incorporation of ferric iron in amphiboles with respect to coexisting pyroxenes. In case of Piwinskii (1968) and Piwinskii (1973), we suggest that pyroxene crystals formed in his high-temperature runs were possibly misidentified as amphiboles, as small amounts of mafic phases can hardly be distinguished unequivocally with XRD techniques; this would explain the apparent stability of amphiboles at high temperatures and the inferred absence of any pyroxenes in the vicinity of the liquidus. Interestingly, in the experiments performed by Eggler (1972), Martel et al. (1999), Hammer et al. (2002), Rutherford and Devine (2003) and Botcharnikov et al. (2008) amphibole is coexisting with orthopyroxene as in our runs, indicating that amphibole is formed by a peritectic reaction between clinopyroxene and residual melt (Holloway and Burnham 1972). On the contrary, Andújar et al. (2016) reported coexistence of amphibole and clinopyroxene in the absence of orthopyroxene. This observation points towards an amphibole-forming peritectic reaction of the type (i) opx + liq $=a m p h+c p x$, while our experiments and the previously mentioned studies favour the alternative reaction (ii) $\mathrm{cpx}+\mathrm{liq}=\mathrm{amph} \pm \mathrm{opx}$. The first occurrence of amphibole in calc-alkaline magmatic systems is related to a diverging peritectic point (Sisson and Grove 1993; Nandedkar et al. 2014; Blatter et al. 2017; Ulmer et al. 2018) inferring that the first occurrence, the stoichiometry of the amphiboleforming reaction and the coexisting phase assemblage (cpx or opx with amphibole) can vary significantly and is very sensitive to bulk system composition, especially to the level of alumina saturation (or more precisely the normative cpx-component) at the onset of amphibole crystallisation. Reconstructions of the phase diagram for differentiating calc-alkaline rocks are provided by Blatter et al. (2017) and Ulmer et al. (2018), illustrating and discussing the topography of the amphibole distributary reaction boundary. In general, a higher alumina saturation of the system (higher ASI, lower normative cpx) favours the formation of amphibole at the expense of clinopyroxene through the peritectic reaction (ii, $c p x+l i q=a m p h \pm o p x)$, while a magma with a lower alumina saturation (higher normative cpx) evolves along the crystallisation path $(\mathrm{i}, \mathrm{opx}+\mathrm{liq}=\mathrm{amph}+\mathrm{cpx})$. Thus, a higher alumina saturation index (ASI) of 0.91 for our tonalite starting material compared to the Santorini Upper Scoriae 1 andesite (ASI of 0.76) investigated by Andújar et al. (2016) explains the contrasting amphibole-forming reactions at the onset of amphibole crystallisation. However, additional parameters influencing the position of the amphibole peritectic point are $x_{\mathrm{Mg}}$ and $\mathrm{fO}_{2}$ impeding the localisation of the reaction boundaries in a simplified compositional space.
The stability fields of Fe-Ti-oxides in intermediate magmatic systems are strongly dependent on oxygen fugacity as well as initial contents of $\mathrm{TiO}_{2}$ and $\mathrm{FeO}_{\text {tot }}$ of the employed starting materials. Thus, published experimental studies reveal a large scatter of $\mathrm{Fe}-\mathrm{Ti}$-oxide saturation temperatures. Overall, a majority of previous studies (Piwinskii 1968; Hammer et al. 2002; Rutherford and Devine 2003; Botcharnikov et al. 2008; Andújar et al. 2016) identified magnetite as the dominating $\mathrm{Fe}-\mathrm{Ti}$-oxide species with saturation temperatures between 900 and $1000{ }^{\circ} \mathrm{C}$. Reported $\mathrm{fO}_{2}$ conditions of these experiments vary between $\mathrm{NNO}$ and $\mathrm{NNO}+2$. Their findings contrast with our experiments, where ilmenite represents the dominant $\mathrm{Fe}-\mathrm{Ti}$-oxide, rarely coexisting with magnetite or ulvospinel $\left(900,850\right.$ and $\left.825^{\circ} \mathrm{C}\right)$ and being replaced by magnetite in the lowest temperature run at $700{ }^{\circ} \mathrm{C}$. Based on this observation, we infer that oxygen fugacities in our runs were consistently slightly lower than NNO although applied redox sensors yielded values in the range of $\mathrm{NNO} \pm 0.5$. Generally, arc magmas span a rather wide range of $\mathrm{fO}_{2}$ conditions $(\mathrm{NNO}-1$ to $\mathrm{NNO}+2)(\mathrm{Gill}$ 1981) and could even be subject to auto-oxidation during fractional crystallisation because of the removal of minerals containing predominantly ferrous iron (Ulmer et al. 2018). Therefore, this study is not applicable to all intermediate systems, in particular with respect to the stability fields of $\mathrm{Fe}-\mathrm{Ti}$-oxides and (consequently) $\mathrm{FeO} / \mathrm{TiO}_{2}$ contents of residual liquids that are sensitive to changes in $\mathrm{fO}_{2}$ conditions.

\section{Melt compositions and liquid line of descent}

Chemical compositions of residual melts fall on the general calc-alkaline differentiation trends with increasing $\mathrm{SiO}_{2}$ and decreasing contents of $\mathrm{Al}_{2} \mathrm{O}_{3}, \mathrm{CaO}, \mathrm{FeO}_{\text {tot }}$ and $\mathrm{MgO}$ with decreasing temperature and evolve from andesitic to high-silica rhyolitic. Experimental liquids are quartz-normative and evolve from metaluminous to slightly peraluminous between 925 and $900{ }^{\circ} \mathrm{C}$ and a silica content of 66-68 wt\%. Peraluminous calc-alkaline rock have often been regarded as the product of contamination or assimilation of mantle-derived magmas with partial melts from a sedimentary source rock (e.g. Clemens et al. 2011), although several previous experimental studies (Muntener et al. 2001; Ulmer 2007; Blatter et al. 2013; Nandedkar et al. 2014; Ulmer et al. 2018) showed that in a limited pressure range of 0.7-1.2 GPa, peraluminous liquids can be derived by fractional crystallisation from metaluminous mafic parents due to the predominant crystallisation of clinopyroxene and amphibole. At lower pressures, the suppression of early clinopyroxene crystallisation due to a shift of the olivine-clinopyroxene cotectic towards more cpx-rich compositions (e.g. Grove et al. 1992) and the dominating presence of anorthite-rich plagioclase (Alonso-Perez et al. 2009) inhibit a melt evolution towards 
corundum normative compositions. However, our results clearly reveal that under water-saturated low-pressure conditions, peraluminous rhyolitic liquids $\left(\mathrm{SiO}_{2}>68 \mathrm{wt} \%\right)$ can be generated by equilibrium crystallisation of an intermediate andesitic/tonalitic magma. The transition from alumina saturated to oversaturated between 925 and $900{ }^{\circ} \mathrm{C}$ coincides with the stabilisation of amphibole. Cawthorn and Brown (1976) already demonstrated that amphibole fractionation is a major process controlling the evolution of residual melts from metaluminous to peraluminous. Likewise, clinopyroxene crystallisation is an efficient way to drive residual liquids towards peraluminous compositions (Chappell et al. 2012). Consequently, in our experiments, $\mathrm{Al}_{2} \mathrm{O}_{3}$ is concentrated in the residual liquid relative to $\mathrm{CaO}$ due to the early crystallisation of clinopyroxene at high temperatures $\left(975-900{ }^{\circ} \mathrm{C}\right)$, followed by amphibole from 900 down to $700{ }^{\circ} \mathrm{C}$ resulting in the evolution trend into the peraluminous compositional field.

\section{Residual melt fraction and rheological implications}

To understand the emplacement and subsequent petrophysical evolution of magma reservoirs at upper crustal levels, knowledge on magma rheology is crucial. Several parameters that control magma rheology (e.g. viscosity or density) depend on crystallinity (crystal fraction), which is a direct function of temperature for a specific magmatic system. For intermediate compositions, the only available experimental datasets on residual melt fraction evolution over the entire temperature range from liquidus to solidus were presented by Piwinskii (1968) and Piwinskii (1973). Melt fractions were, however, established by visual estimation and, thus, are questionable. The melting experiments performed in this study complement these data from 700 to $1000{ }^{\circ} \mathrm{C}$, where residual melt fractions were calculated by mass balance regression supplemented by image processing for experiments in the critical range $\left(700-850^{\circ} \mathrm{C}\right)$. To apply the residual melt fraction trend to basic principles on magma rheology, values had to be transformed from weight percent (wt\%) to volume percent (vol. \%). For this, densities of experimental residual liquids were calculated after the method described by Lange and Carmichael (1987). $\mathrm{H}_{2} \mathrm{O}$ contents of residual liquids were derived by MagmaSat (Ghiorso and Gualda 2015) assuming saturated conditions and calculated concentrations varied between 6.0 and 6.4 $w t \%$. Mineral densities were estimated with the MATLAB toolbox from Abers and Hacker (2016) assuming ideal mixing among mineral endmembers for plagioclase, pyroxenes and biotite. For amphibole, the implemented phase "hornblende" was used as an approximation. Calculated densities of mineral phases do not vary significantly over the studied compositional range but still reveal consistent evolution trends (densities of mafic phases continuously increase with differentiation due to increasing iron content and plagioclase densities decrease due to increasing albite contents).

Figure 10 compares residual melt fraction from this study with data from Piwinskii (1968), (1973) and a modelled melt fraction evolution calculated with the thermodynamic software package rhyolite-MELTS (Gualda et al. 2012). MELTS calculations were performed on the bulk chemical composition of the starting material TML and an oxygen fugacity fixed at NNO. System $\mathrm{H}_{2} \mathrm{O}$ content was reduced from 6 to $5.4 \mathrm{wt} \%$ since with the former value the MELTS algorithms did not converge on a liquidus temperature due to the presence of a free fluid phase when the model attempts to converge on a single-phase melt.

Considering our own data, three major phases of melt fraction evolution with temperature can be identified: an initial near-linear correlation with decreasing temperature from the liquidus down to $850{ }^{\circ} \mathrm{C}$, followed by a second segment forming a plateau between 55 and 45 vol. \% from 850 to $750{ }^{\circ} \mathrm{C}$ and a third segment characterised by a rapid linear drop towards the solidus $\left(750\right.$ to $\left.<700{ }^{\circ} \mathrm{C}\right)$ coinciding with the onset of quartz crystallisation. We attribute the occurrence of this melt fraction plateau to the observation that residual melts are already approaching a rhyolitic composition around $875^{\circ} \mathrm{C}\left(\mathrm{SiO}_{2}>71 \mathrm{wt} \%\right)$, inferring that only minor additional crystallisation (mainly plagioclase with very limited mafic phases) occurs upon further cooling until quartz saturation is finally reached between 725 and $750{ }^{\circ} \mathrm{C}$. Data from Piwinskii (1973) agree with our findings down

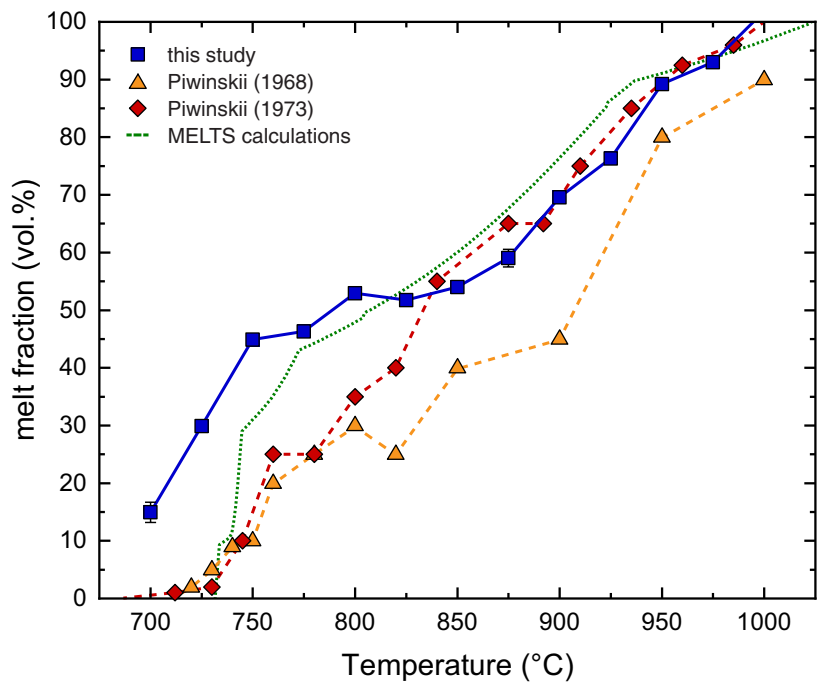

Fig. 10 Melt fractions (vol. \%) vs. temperature for a tonalitic system at $200 \mathrm{MPa}$. Blue squares represent experimental results of this study. Error bars are only shown in case they are larger than the symbols. Orange triangles correspond to melt fractions reported by Piwinskii (1968) and red diamonds to data by Piwinskii (1973). In both studies, melt fractions were established based on visual estimation. The green dotted curve represents the evolution trend modelled with rhyoliteMELTS (Gualda et al. 2012) (see text for more details) 
to $850{ }^{\circ} \mathrm{C}$ but instead of exhibiting a plateau-like behaviour, the melt fraction continues to decrease linearly towards the solidus. The Piwinskii (1968) data align consistently and distinctly at least 10 vol. \% below our results and, thus, permanently underestimate the residual melt fractions for a given temperature. The melt fraction evolution trend calculated with MELTS results a rather similar evolution pattern with decreasing temperature as our data, varying by 5-10 vol. \% around the experimental trend from 975 to $775{ }^{\circ} \mathrm{C}$. At $800-825^{\circ} \mathrm{C}$, a slight flattening out, similar to but less distinct compared to our experiments, can be observed. The rapid decrease in residual melt fraction below $775^{\circ} \mathrm{C}$ indicates that MELTS predicts quartz saturation at slightly higher temperatures. Consequently, the granitic minimum with the eutectic crystallisation of $\mathrm{kfsp}+$ plag $+\mathrm{qtz} \pm$ biotite is reached earlier resulting in a solidus temperature of $735{ }^{\circ} \mathrm{C}$. The deviation of the rhyolite-MELTS trend from the experimental one at temperatures in excess of $975{ }^{\circ} \mathrm{C}$ is related to an overestimation of the liquidus temperature $\left(1023{ }^{\circ} \mathrm{C}\right)$.

Focussing on our experimental results, a magma crystallinity of 40-55 vol. \%, the so-called rigid percolation threshold (RPT) (Vigneresse et al. 1996), is reached between 880 and $750{ }^{\circ} \mathrm{C}$. In this temperature range, tonalitic magma reservoirs cross the transition from a mobile magma (dilute crystal suspension) with the potential to be eruptible to a rather rigid crystalline mush. The observed plateau between 850 and $750{ }^{\circ} \mathrm{C}$ infers that water-saturated intermediate composition magma reservoirs remain in this rheologic transition zone for a long-time period and might become remobilised by injection of hotter, more primitive magmas from lower levels. The melt fraction-temperature relationship further infers that at $200 \mathrm{MPa}$, an andesitic/tonalitic magma is only able to erupt to the surface or move as an integral magma body when its temperature exceeds $850{ }^{\circ} \mathrm{C}$. Such temperatures are further constrained by thermal modelling of the contact aureole of the Southern-Central Adamello Batholith by Floess and Baumgartner (2015) resulting that the peak metamorphic conditions and extent of the contact aureole required tonalite magma temperatures at the time of emplacement of 850-950 ${ }^{\circ} \mathrm{C}$. At lower temperatures, the magma viscosity becomes too high for efficient movements due to crystal interlocking. Under these conditions, other processes will take over, most prominently deformation-assisted extraction of interstitial liquids from the crystal mush, e.g. favoured by strain partitioning forming melt-enriched and crystal-rich regions (Pistone et al. 2013) or realigning of crystals in the mush over prolonged time periods during compaction (crystal repacking) (Bachmann and Huber 2019). At 40 vol. $\%$ crystallinity $\left(875^{\circ} \mathrm{C}\right)$, the experimental liquid is already of a rhyolitic composition (71 $\mathrm{wt} \% \mathrm{SiO}_{2}$ ) and becomes high-silica rhyolitic at 55 vol. \% crystal content $\left(77.5 \mathrm{wt} \% \mathrm{SiO}_{2}\right)$. This observation supports the model of Bachmann and Bergantz (2004) and Bachmann and Huber (2019) on the formation of crystal-poor rhyolites, which is based on the observations by Bachmann et al. (2002) or Schmitt et al. (2003) that interstitial liquids of intermediate composition magmatic bodies are of rhyolitic composition at crystallinities of 40-50 vol. \%. Consequently, extraction of high-silica rhyolitic liquids through a combination of hindered settling, compaction with crystal repacking/ micro-settling and compaction with crystal deformation is a plausible process while large intermediate magma bodies are cooling from 880 to $750{ }^{\circ} \mathrm{C}$. These liquids may then rise towards the surface and erupt as crystal-poor rhyolites leaving behind a crystalline mush at depth. In case of perfect melt extraction, mush residues with gabbroic cumulate mineral assemblages (plag dominated with amphibole and pyroxenes) are left behind. However, since perfect melt extraction is a rather unlikely process in nature, some residual liquid will remain as intercumulus phase in the crystal framework. Upon further cooling and solidification, this melt will modify the cumulate mineral assemblage (peritectic formation of additional amphibole at the expense of orthopyroxene as well as late-stage crystallisation of biotite, quartz and potassic feldspar) resulting in a rock resembling in terms of mineralogy and chemistry a mafic tonalite as partly observed and identified as residuum after (limited) melt extraction in the Adamello Batholith (Fiedrich et al. 2017).

\section{Comparison with natural rock record}

Natural rocks in the Tertiary Adamello Batholith in Northern Italy span a wide range of bulk chemical compositions ranging from mantle-derived primitive high-Mg basalts to aplitic dikes with high-silica rhyolitic compositions. Therefore, we compare our experimental liquid line of descent (LLD) with the existing natural rock record. For this approach, we selected XRF bulk rock data (Bianchi et al. 1970; Del Moro et al. 1983; Macera et al. 1983; Ulmer et al. 1983; Blundy and Sparks 1992; Verberne 2013; Hurlimann et al. 2016; P. Ulmer, unpublished data) covering the compositional range of the experimental series (intermediate to more differentiated granitoids and dikes), i.e. all rocks with $\mathrm{SiO}_{2}$ distinctly lower than the starting material $(60.8 \mathrm{wt} \%)$ were neglected. Additional care was taken to avoid rocks clearly representing cumulates or crystal mushes that lost interstitial melts due to late-stage magmatic processes. Natural data are plotted together with experimental liquids as binary oxide variation diagrams in Fig. 11.

Overall, the natural rock record agrees well with the experimental liquid line of descent, implying that intermediate and more evolved plutonic rocks in the Adamello are genetically related where the later can be generated by lowpressure differentiation through equilibrium crystallisation 
Fig. 11 Major oxide variation diagrams comparing plutonic rocks from the Adamello Batholith (Bianchi et al. 1970; Del Moro et al. 1983; Macera et al. 1983; Ulmer et al. 1983; Blundy and Sparks 1992; Verberne 2013; Hurlimann et al. 2016; P. Ulmer, unpublished data) with the experimental liquid line of descent of this study. Abbreviations for natural rock suites are as follows: $\mathrm{RdC}-\mathrm{Re}$ di Castello unit (Southern Adamello), Listino-Listino Ring Complex (Southern Adamello), Blumone-Blumone unit (Southern Adamello), WA/CA-Western and Central Adamello, Ada-North-Presanella and Avio superunits (Northern Adamello), Val Fredda-Val Fredda Complex (Southern Adamello), Dikes-various dike rocks from the Southern Adamello
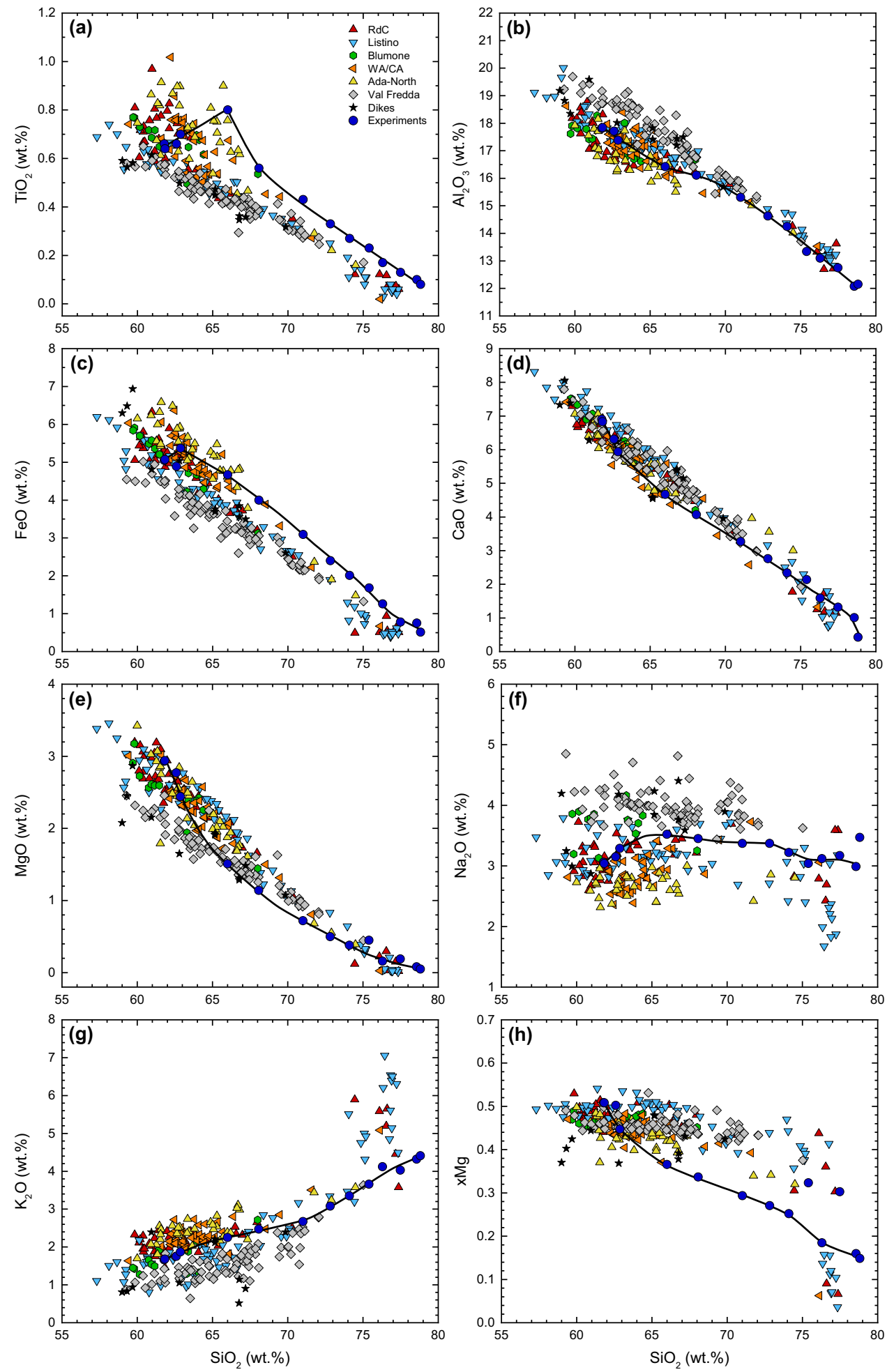

of the previous ones and melt extraction at various stages. However, since trends defined by natural data are (nearly) linear for most oxides the possibility of mixing between different magmas being involved in the formation and differentiation of the Adamello intermediate rocks cannot be excluded a priori. Subtle differences between experimental and natural compositional trends can be observed for some oxide components and/or for particular rock suites. $\mathrm{TiO}_{2}$ (Fig. 11a) shows the largest discrepancy between experiments and Adamello data, since even the evolution pattern is different (continuous decrease in case of the natural rocks compared to an initial increase followed by a decline for 
the experimental LLD). This mismatch can be explained by the saturation behaviour of Fe-Ti-oxides. Experimental $\mathrm{fO}_{2}$ must have been slightly lower than in the natural case resulting in a delayed saturation of ilmenite or magnetite and, thus, less efficient removal of $\mathrm{TiO}_{2}$ from the melt. In fact, Blundy and Sparks (1992) performed oxybarometry on mafic rocks from the Val Fredda Complex and established oxygen fugacities around $\mathrm{NNO}+0.5$ to $\mathrm{NNO}+1$, which are about $1 \log$ unit higher than experimental ones constrained by $\mathrm{Co}-\mathrm{Pd}$ redox sensors (around $\mathrm{NNO} \pm 0.5$ ). This explanation is supported by the $\mathrm{FeO}$ characteristics (Fig. 11c). The experimental iron trend plots consistently above the natural data trend for evolved compositions ( $>65 \mathrm{wt} \% \mathrm{SiO}_{2}$ ), clearly supporting earlier $\mathrm{Fe}$-Ti-oxide phase saturation in the natural rocks. Unlike the Southern Adamello rocks, data from the Northern and Western/Central Adamello partly overlap in terms of $\mathrm{TiO}_{2}$ and $\mathrm{FeO}$ with the experiments implying that several lithologies in these units differentiated at oxygen fugacities slightly lower than the rocks forming the southern (older, less crustally contaminated) part of the Adamello. For $\mathrm{Al}_{2} \mathrm{O}_{3}$, natural data closely follow the experimental trend with the exception of the intermediate rocks from the Val Fredda unit that consistently plot above the experimental trend. Based on mineral chemistry and phase assemblages, Blundy and Sparks (1992) and Nimis and Ulmer (1998) concluded that the Val Fredda magmas experienced a highpressure fractionation prior to emplacement at shallow levels. Differentiation at high pressures in the lower crust results in residual liquids with higher alumina contents and a pronounced affinity towards peraluminous compositions (Nandedkar et al. 2014; Ulmer et al. 2018) and, thus, explains the deviation of the Val Fredda unit from the general $\mathrm{Al}_{2} \mathrm{O}_{3}$ differentiation trend. Natural $\mathrm{CaO}$ (Fig. 11d) and $\mathrm{MgO}$ (Fig. 11e) evolution patterns are perfectly reproduced by the experimental liquid line of descent. Furthermore, the agreement is convincing in case of the alkalis (Fig. 11f , g). With the exception of some highly differentiated rocks of minor volumetric extent with higher potassium and lower sodium contents the natural data follow the experimental trends. This apparent mismatch in the alkali contents between these high-silica rocks and the experimental trend is most likely linked to the hydrothermal-magmatic origin of the later, representing originally high-silica rhyolitic melts extracted from crystallising tonalitic mushes on small, local scales (as described in the previous section), which have later been modified chemically by late-stage magmatic fluids (and/or melts) with distinctly higher concentrations of potassium. Remarkably, the Val Fredda rocks exhibit higher $\mathrm{Na}_{2} \mathrm{O}$ and lower $\mathrm{K}_{2} \mathrm{O}$ contents compared to the experimental data set. This can be related to (1) the low-K characteristics of this unit and (2) diminished plagioclase fractionation due to high-pressure differentiation. The mismatch between Adamello plutonics and experimental data in terms of $x_{\mathrm{Mg}}$
(Fig. 11h) can again be related to higher $\mathrm{FeO}$ contents of experimental residual liquids due to lower $\mathrm{fO}_{2}$ conditions during differentiation.

\section{Zircon saturation}

Zircon represents the most important accessory mineral phase in intermediate to felsic magmatic systems as it (1) is the prime mineral phase to obtain geochronologic information at super-solidus conditions; (2) allows the reconstruction of the coexisting liquid evolution utilising a number of geochemical tracer elements (e.g. HFSE or REE), and (3) behaves nearly completely inert regarding late-stage modifications. A number of experimental studies have investigated the saturation behaviour of zircon in natural and synthetic melts. Pioneering work was performed by Watson and Harrison (1983) presenting an empirical zircon saturation model linking the zirconium content of a liquid in equilibrium with zircon to the melt composition and temperature. More recently, Boehnke et al. (2013) published a revised version of the original Watson and Harrison (1983) model while Gervasoni et al. (2016) proposed a new zircon saturation model applicable to a wider variety of natural rocks. These models were recently supplemented by additional experiments and a new algorithm by Borisov and Aranovich (2019). Due to experimental and analytical difficulties, all proposed models are only poorly constrained at geologically relevant conditions of temperatures below $900{ }^{\circ} \mathrm{C}$ and bulk zirconium contents lower than $400 \mathrm{ppm}$ where zircon saturation in hydrous, intermediate to felsic calk-alkaline system occurs. Nevertheless, these saturation models have been extensively applied to predict crystallisation temperatures of zircons for natural rock samples targeting at quantifying temperature (and or crystallinity) conditions of zircon crystallisation and linking this information with ages or ageranges determined by $\mathrm{U}-\mathrm{Th}-\mathrm{Pb}$ geochronology (e.g. Barboni et al. 2015). However, in most cases, this procedure is not straightforward as it is a major challenge to estimate the zirconium content of the melt and its chemical composition at the onset of zircon crystallisation.

Our data offer the unique opportunity to test the application of these zircon saturation models to a natural calcalkaline system taking advantage of the fact that we know the chemical evolution of the residual melt composition with decreasing temperature. This allows us to directly calculate zirconium saturation levels for each experiment for all four published saturation models and compare modelled with measured zirconium contents of the experimental liquids (Fig. 12). In the experimental system doped with $1420 \pm 80 \mathrm{ppm}$ of $\mathrm{Zr}$, zircon is first present in the experiments at $950-975{ }^{\circ} \mathrm{C}$ indicating that $\mathrm{Zr}$-melt contents for lower temperature runs correspond to zircon saturation levels. With respect to our measured experimental data (blue 


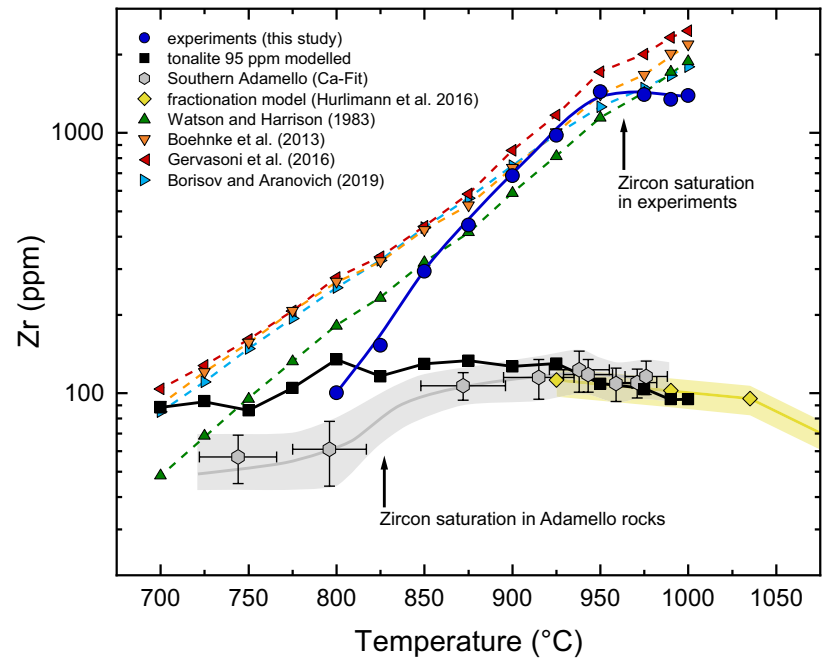

Fig. 12 Comparison of experimentally derived $\mathrm{Zr}$ contents of residual liquids (with zircon saturation reached at $950-975{ }^{\circ} \mathrm{C}$ ) with predicted zirconium saturation levels calculated with existing saturation models (Watson and Harrison 1983; Boehnke et al. 2013; Gervasoni et al. 2016; Borisov and Aranovich 2019). The modelled Zr-evolution of the natural tonalite used as starting material in this study is shown as black squares, while the grey hexagons correspond to compositions of natural rocks from the Adamello representing residual melts of the tonalitic system with temperatures calculated from their $\mathrm{CaO}$ contents. The yellow diamonds represent the results of the fractionation model proposed by Hurlimann et al. (2016) starting from a primary high-Mg basalt (see text for further explanations)

curve), all four models significantly overestimate zircon solubility at temperatures below $850{ }^{\circ} \mathrm{C}$. Watson and Harrison (1983) (in green) provide the closest match (although with a significant offset), while Boehnke et al. (2013) (in orange), Gervasoni et al. (2016) (in red) and Borisov and Aranovich (2019) (in light blue) result distinctly higher zirconium concentrations.

In a next step, we evaluated the predicted zircon saturation temperature for the studied tonalite rock. For this, we require (1) the initial bulk magma zirconium content and (2) the subsequent evolution of $\mathrm{Zr}$ concentrations of residual liquids with ongoing differentiation. Averaged bulk rock XRF and LA-ICP-MS data (e.g. Verberne 2013) of the tonalites of the specific unit of the Southern Adamello Batholith (TML) employed as starting material resulted a zirconium content of $95 \pm 10 \mathrm{ppm}$. The evolution of residual melts during differentiation was modelled assuming partitioning of zirconium among the liquid and the experimentally observed mineral phases (ignoring any potential zircon crystallisation). Zirconium mineral-melt partition coefficients were taken either from literature (Bedard (2006) for plagioclase, Bedard (2014) for pyroxenes and Nandedkar et al. (2016) for amphibole) or from the GERM database (biotite and ilmenite, summary compiled in Electronic Supplementary Material ESM 5). Experimental phase proportions required for calculations were taken from Table 2. The evolution of melt $\mathrm{Zr}$ contents was approached with the equilibrium crystallisation equation; results are shown by black squares connected by a black curve in Fig. 12. The spike in the calculated trend at $800{ }^{\circ} \mathrm{C}$ is related to an inversion of amphibole and orthopyroxene proportions due to the incapability of the mass balance regression algorithm to distinguish between multiple mafic phases with similar compositions (as already discussed in the results section). Partition coefficients for zirconium are significantly higher for amphibole than orthopyroxene (more than a factor of ten) and a decrease in amph proportions and coeval increase in opx amounts thus explains the apparent reversal in the $\mathrm{Zr}$-evolution trend as a function of temperature.

The onset of zircon crystallisation is predicted for each saturation model as the cross-over of the predicted $\mathrm{Zr}$-melt trend with the respective saturation model curve. Therefore, our own $\mathrm{Zr}$ solubility data suggest zircon saturation at around $810^{\circ} \mathrm{C}$, while Watson and Harrison (1983) yield a temperature of $750{ }^{\circ} \mathrm{C}$ and Boehnke et al. (2013), Gervasoni et al. (2016) as well as Borisov and Aranovich (2019) result saturation temperatures at or below $700{ }^{\circ} \mathrm{C}$. Consequently, the more recent models severely overestimate zirconium solubility at low magmatic temperatures $\left(<800^{\circ} \mathrm{C}\right)$ predicting zircon saturation temperatures close to or even below the inferred solidus. Referring back to Fig. 10, established zircon saturation temperatures after Boehnke et al. (2013), Gervasoni et al. (2016) and Borisov and Aranovich (2019) $\left(\leq 700{ }^{\circ} \mathrm{C}\right)$ imply that all zircons present in the solidified tonalite must have crystallised at the final emplacement depth at shallow levels and none could have been derived from deeper reservoirs during magma ascent. Therefore, the age range observed for the zircon population is entirely assigned to emplacement and solidification at the level of final intrusion of the magma in the shallow crust because melt fractions at zircon saturation are below 15 vol. \% and, thus, distinctly below the rigid percolation threshold (RPT) (45-60 vol. \% melt) in the (immobile) mush-state of the magmatic system. This conclusion, however, challenges the common interpretation of multiple populations of zircon ages found in natural rocks where older zircons are inferred to have crystallised at deeper levels and brought up to shallow depths during magma emplacement (e.g. Schaltegger et al. 2009; Verberne 2013), again exemplifying the ambiguity of the recent models at low magmatic temperatures. The natural rock record of the Southern Adamello intermediate to felsic granitoids reveals, in contrast, that zircon did not only crystallise at the very end of magmatic differentiation but over a significant temperature range as exemplified by Ti-inZircon temperatures determined by Broderick et al. (2015) ranging from near solidus $\left(680-700{ }^{\circ} \mathrm{C}\right)$ to $850{ }^{\circ} \mathrm{C}$. Likewise, Broderick (2013) extracted zircons directly from thin sections allowing identification of coexisting paragenesis 
and found idiomorphic zircons enclosed in amphibole and biotite that themselves contained ilmenite and apatite inclusions clearly indicating that zircon crystallisation initiated well above the solidus.

In a last step, we compared our modelled zirconium melt evolution, the experimental data and the saturation model predictions with the natural rock record of the Adamello Batholith. We utilised bulk rock data representing evolved intermediate to felsic compositions covering the entire range from 60 to $77 \mathrm{wt} \% \mathrm{SiO}_{2}$ including highly evolved aplites representing residual liquids of the tonalitic system (Bianchi et al. 1970; Macera et al. 1983; Ulmer et al. 1983, Blundy and Sparks 1992; Verberne 2013; Hurlimann et al. 2016; P. Ulmer, unpublished data). Analyses were grouped based on $\mathrm{MgO}$ contents and averaged resulting in nine different populations (grey hexagons) consisting each of 10-35 single data points. Temperatures of melt extraction from the tonalitic bulk system were estimated using a parametrisation for $\mathrm{CaO}$ (in wt\%) based on the experimental liquid line of descent $\left(\mathrm{T}\left({ }^{\circ} \mathrm{C}\right)=(-411.7 \pm 33.0) * \exp [-\mathrm{CaO} /(4.35 \pm\right.$ $0.79)]+(1061.3 \pm 39.4))$ that closely follows the natural rock trend (Figs. 4 and 11). Additionally, we employed the fractionation model for the Southern Adamello proposed by Hurlimann et al. (2016) to calculate the enrichment of zirconium in the residual liquid during fractional crystallisation of a high- $\mathrm{Mg}$ basalt representing the primary parental magma. This model includes five fractionation steps starting from a primary high-Mg basalt and ending with a melt of dacitic composition closely resembling residual liquids of our experimental series. Averaged analyses of the high- $\mathrm{Mg}$ basalt resulted $44 \pm 5 \mathrm{ppm}$ in the primary liquid that evolves to $102 \mathrm{ppm}$ in the andesite and $113 \mathrm{ppm}$ in the dacite. Only the last three steps of the model are shown in Fig. 12 by the yellow diamonds. The yellow band corresponds to the uncertainty range introduced by the standard deviation of $\pm 5 \mathrm{ppm}$ on the initial zirconium content of the primary liquid. The Hurlimann et al. (2016) model perfectly overlaps in its last stages with the natural rock record (grey hexagons) as well as with the evolution of the differentiating tonalitic system calculated based on the experimental phase proportions (black curve).

Natural rocks overlap with the modelled tonalite trend from 1000 to $850^{\circ} \mathrm{C}$ but show a sudden decrease of zirconium contents between 800 and $850{ }^{\circ} \mathrm{C}$ that we interpret as the onset of zircon crystallisation, agreeing well with a zircon saturation temperature of $810^{\circ} \mathrm{C}$ predicted by our experiments. This further supports the validity of our modelling approach and again demonstrates the likely overestimation of $\mathrm{Zr}$ concentration of existing zircon saturation models at petrologically relevant conditions. A slightly lower absolute zirconium solubility for the natural rocks plotting at $800{ }^{\circ} \mathrm{C}$ (and $750{ }^{\circ} \mathrm{C}$ ) of around $60 \mathrm{ppm}$ compared to the experimental liquids $\left(100 \mathrm{ppm}\right.$ at $\left.800{ }^{\circ} \mathrm{C}\right)$ might be explained by the higher titanium activity of the later due to slightly more reducing $\mathrm{fO}_{2}$ conditions (compare previous section). Ti and $\mathrm{Zr}$ both belong to the high-field-strength elements (HFSE) inferring that these components behave chemically similarly in magmatic systems implying that their activities might be coupled. Consequently, a higher Ti-activity in the melt could result in an increased solubility of zirconium and, therefore, explain the observed slight discrepancy between experimentally determined solubility levels and natural rocks plotting at low magmatic temperatures.

Overall, the experimentally determined Zr-saturation evolution as a function of decreasing temperature is consistent with modelled and naturally observed $\mathrm{Zr}$ concentrations. Inferred zircon saturation for the specific granitoids system investigated results in overall higher zircon saturation temperatures than predicted by existing models. However, these higher temperatures are more compatible with petrographic and thermometric observations inferring that zircon saturation occurred already considerably above the solidus. More generally, it is evident from Fig. 12 that the zircon saturation surface constrained by our experiments (blue curve) exhibits a rather steep slope from 850 to $800{ }^{\circ} \mathrm{C}$ with $\mathrm{Zr}$-melt saturation contents decreasing from 300 to $100 \mathrm{ppm}$. The majority of global intermediate calc-alkaline rocks have comparable bulk rock zirconium contents covering this exact range (e.g. Cascades: $140 \pm 60$ or Andes: $150 \pm 90$, values compiled from various publically accessible data repositories, e.g. GEOROC, GERM) implying that zircon saturation occurs in a narrow temperature interval between 800 and $850{ }^{\circ} \mathrm{C}$ for most arc rocks in case they evolve along liquid lines of descent similar to the one derived in this study.

\section{Conclusion}

A series of melting experiments was conducted providing a consistent data set on the closed system differentiation of intermediate magmatic intrusion at a pressure of $200 \mathrm{MPa}$ corresponding to 5-7 km depth. A well-defined crystallisation sequence from 1000 to $700{ }^{\circ} \mathrm{C}$ could be established with plagioclase, orthopyroxene and clinopyroxene identified as near-liquidus phases. Amphibole joins the solid assemblage at the expense of clinopyroxene at $900{ }^{\circ} \mathrm{C}$ co-precipitating with ilmenite and apatite. Biotite saturates at $750{ }^{\circ} \mathrm{C}$ and orthopyroxene disappears at $725{ }^{\circ} \mathrm{C}$ contemporarily with the onset of quartz crystallisation. In general, the observed mineral assemblages agree with previous studies, although published data on saturation temperatures and phase compositions especially for pyroxenes and amphiboles show a rather large variability. A number of parameters exert major control on mafic silicates' phase stabilities (e.g. bulk system composition or $\mathrm{fO}_{2}$ ) as discussed in the "Results" section. Mineral and residual melt compositions obtained in this study reveal 
consistent trends with decreasing temperature, providing new constraints on the late-stage evolution of intermediate calcalkaline systems of similar composition. Residual liquids evolve from the metaluminous into the peraluminous compositional field at around $900{ }^{\circ} \mathrm{C}$. Mafic mineral phases (pyroxenes and amphiboles) show a consistent decrease in $x_{\mathrm{Mg}}$ and coexisting plagioclases in anorthite contents with decreasing equilibration temperature. Experimentally established melt fractions drop near linearly from 975 to $850{ }^{\circ} \mathrm{C}$ followed by a plateau at $55-45$ vol. $\%$ between 850 and $750{ }^{\circ} \mathrm{C}$ and a final decrease from 750 to $700{ }^{\circ} \mathrm{C}$, where still 15 vol. $\%$ melt persists. Our experimentally derived melt fraction-temperature relationship agrees rather well with rhyolite-MELTS calculations. Only when approaching the solidus, the modelled trend deviates from the experimental one. Thus, the MELTS algorithm can be applied to model the melt fraction evolution as a function of decreasing temperature in a cooling magma body even in hydrous magmatic systems. One should, however, keep in mind that the calculated phase assemblages are significantly different from the experimentally derived ones as rhyolite-MELTS does not result amphibole-bearing compositions over the entire crystallisation interval investigated. Plutonic rocks from the Adamello Batholith closely follow the major oxide evolution patterns exhibited by the experimental liquid line of descent. Subtle differences for $\mathrm{TiO}_{2}$ and $\mathrm{FeO}$ can be explained by variations of $\mathrm{fO}_{2}$ conditions during differentiation. Zircon saturation along the LLD was determined and agrees closest with the model of Watson and Harrison (1983) while the more recent calibrations (Boehnke et al. 2013; Gervasoni et al. 2016; Borisov and Aranovich 2019) severely overestimate zirconium solubility at conditions relevant for the investigated calc-alkaline system resulting in significant underestimation of saturation temperatures. The experimentally derived $\mathrm{Zr}$-saturation behaviour is consistent with the natural rock record inferring zircon saturation at $800-830^{\circ} \mathrm{C}$ and corresponding melt fractions of ca. 50 vol. \%.

Acknowledgements This work was supported by the ETH research grant ETH-14 16-1. We would like to thank Lukas Martin for assistance during SEM-EDS and EPMA analyses, Marcel Guillong for support during LA-ICP-MS measurements and Nico Kuter for mentoring during initial experimental work in the externally heated pressure vessel lab. We are grateful to Olivier Bachmann, Luca Caricchi and Othmar Müntener for constructive discussions related to this project. Thoughtful and constructive reviews from Bruno Scaillet and an anonymous reviewer as well as the editorial handling by Mark Ghiorso are gratefully acknowledged which helped to improve the presentation of this paper.

Open Access This article is distributed under the terms of the Creative Commons Attribution 4.0 International License (http://creativeco mmons.org/licenses/by/4.0/), which permits unrestricted use, distribution, and reproduction in any medium, provided you give appropriate credit to the original author(s) and the source, provide a link to the Creative Commons license, and indicate if changes were made.

\section{References}

Abers GA, Hacker BR (2016) A MATLAB toolbox and Excel workbook for calculating the densities, seismic wave speeds, and major element composition of minerals and rocks at pressure and temperature. Geochem Geophy Geosy 17:616-624. https:// doi.org/10.1002/2015GC006171

Allen JC, Boettcher AL, Marland G (1975) Amphiboles in andesite and basalt: I. Stability as a function of P-T- $\mathrm{fO}_{2}$. Am Mineral 60:1069-1085

Alonso-Perez R, Muntener O, Ulmer P (2009) Igneous garnet and amphibole fractionation in the roots of island arcs: experimental constraints on andesitic liquids. Contrib Mineral Petrol 157:541558. https://doi.org/10.1007/s00410-008-0351-8

Amma-Miyasaka M, Nakagawa M (2002) Origin of anorthite and olivine megacrysts in island-arc tholeiites: petrological study of 1940 and 1962 ejecta from Miyake-jima volcano, Izu-Mariana arc. J Volcanol Geoth Res 117:263-283. https://doi.org/10.1016/ S0377-0273(02)00224-X

Andújar J, Scaillet B, Pichavant M, Druitt TH (2016) Generation conditions of dacite and rhyodacite via the crystallization of an andesitic magma. Implications for the plumbing system at Santorini (Greece) and the origin of tholeiitic or calc-alkaline differentiation trends in arc magmas. J Petrol 57:1887-1920. https ://doi.org/10.1093/petrology/egw061

Bachmann O, Bergantz GW (2004) On the origin of crystal-poor rhyolites: extracted from batholithic crystal mushes. J Petrol 45:1565-1582. https://doi.org/10.1093/petrology/egh019

Bachmann O, Huber C (2019) The inner workings of crustal distillation columns; the physical mechanisms and rates controlling phase separation in silicic magma reservoirs. J Petrol 60:3-18. https:// doi.org/10.1093/petrology/egy 103

Bachmann O, Dungan MA, Lipman PW (2002) The Fish Canyon magma body, San Juan volcanic field, Colorado: rejuvenation and eruption of an upper-crustal batholith. J Petrol 43:1469-1503. https://doi.org/10.1093/petrology/43.8.1469

Barboni M, Annen C, Schoene B (2015) Evaluating the construction and evolution of upper crustal magma reservoirs with coupled $\mathrm{U} / \mathrm{Pb}$ zircon geochronology and thermal modeling: a case study from the Mt. Capanne pluton (Elba, Italy). Earth Planet Sc Lett 432:436-448. https://doi.org/10.1016/j.eps1.2015.09.043

Barr JA, Grove TL (2010) AuPdFe ternary solution model and applications to understanding the $\mathrm{fO}_{2}$ of hydrous, high-pressure experiments. Contrib Mineral Petrol 160:631-643. https://doi. org/10.1007/s00410-010-0497-z

Bedard JH (2006) Trace element partitioning in plagioclase feldspar. Geochim Cosmochim Ac 70:3717-3742. https://doi. org/10.1016/j.gca.2006.05.003

Bedard JH (2014) Parameterizations of calcic clinopyroxene-Melt trace element partition coefficients. Geochem Geophy Geosy 15:303-336. https://doi.org/10.1002/2013GC005112

Bianchi A, Callegari E, Jobstraibizer PG (1970) I tipi fondamentali petrogenetici del Plutone dell'Adamello. Tonaliti-quarzodioritigranodioriti e loro varietà leucocratiche. Mem Ist Geol Mineral Univ Padova 27:1-148

Blatter DL, Sisson TW, Hankins WB (2013) Crystallization of oxidized, moderately hydrous arc basalt at mid- to lower-crustal pressures: implications for andesite genesis. Contrib Mineral Petrol 166:861-886. https://doi.org/10.1007/s00410-013-0920-3

Blatter DL, Sisson TW, Hankins WB (2017) Voluminous arc dacites as amphibole reaction-boundary liquids. Contrib Mineral Petrol 172:27. https://doi.org/10.1007/s00410-017-1340-6

Blundy JD, Sparks RSJ (1992) Petrogenesis of mafic inclusions in granitoids of the Adamello Massif, Italy. J Petrol 33:1039-1104. https://doi.org/10.1093/petrology/33.5.1039 
Boehnke P, Watson EB, Trail D, Harrison TM, Schmitt AK (2013) Zircon saturation re-revisited. Chem Geol 351:324-334. https:// doi.org/10.1016/j.chemgeo.2013.05.028

Bole M (2012) Petrology and geochemistry of gabbro-tonalite association in the Blumone area (South of Adamello, Italy). MSc Thesis, ETH Zurich

Borisov A, Aranovich L (2019) Zircon solubility in silicate melts: new experiments and probability of zircon crystallization in deeply evolved basic melts. Chem Geol 510:103-112. https:// doi.org/10.1016/j.chemgeo.2019.02.019

Botcharnikov RE, Holtz F, Almeev RR, Sato H, Behrens H (2008) Storage conditions and evolution of andesitic magma prior to the 1991-95 eruption of Unzen volcano: constraints from natural samples and phase equilibria experiments. J Volcanol Geoth Res 175:168-180. https://doi.org/10.1016/j.jvolgeores.2008.03.026

Broderick C (2013) Timescales and petrologic processes during incremental pluton assembly: a case study from the Val Fredda Complex, Adamello Batholith, N. Italy. PhD Thesis, University of Geneva

Broderick C, Wotzlaw JF, Frick DA, Gerdes A, Ulianov A, Guenther D, Schaltegger U (2015) Linking the thermal evolution and emplacement history of an upper-crustal pluton to its lowercrustal roots using zircon geochronology and geochemistry (southern Adamello batholith, N. Italy). Contrib Mineral Petrol 170:28. https://doi.org/10.1007/s00410-015-1184-x

Cadoux A, Scaillet B, Druitt TH, Deloule E (2014) Magma storage conditions of large Plinian eruptions of Santorini Volcano (Greece). J Petrol 55:1129-1171. https://doi.org/10.1093/petro logy/egu021

Callegari E (1966) Osservazioni su alcune cummingtoniti del Massiccio dell'Adamello. Memorie de S lla Accademia Patavina di Scienze, Lettere ed Arti Classe di Scienze Matematiche e Naturali 78:273-310

Cawthorn RG, Brown PA (1976) Model for formation and crystallization of corundum-normative calc-alkaline magmas through amphibole fractionation. J Geol 84:467-476. https://doi. org/10.1086/628212

Chappell BW, Bryant CJ, Wyborn D (2012) Peraluminous I-type granites. Lithos 153:142-153. https://doi.org/10.1016/j.litho s.2012.07.008

Clemens JD, Stevens G, Farina F (2011) The enigmatic sources of I-type granites: the peritectic connexion. Lithos 126:174-181. https://doi.org/10.1016/j.lithos.2011.07.004

Clowe CA, Popp RK, Fritz SJ (1988) Experimental investigation of the effect of oxygen fugacity on ferric-ferrous ratios and unitcell parameters of four natural clinoamphiboles. Am Mineral 73:487-499

Costa F, Scaillet B, Pichavant M (2004) Petrological and experimental constraints on the pre-eruption conditions of Holocene dacite from Volcán San Pedro ( $36^{\circ} \mathrm{S}$, Chilean Andes) and the importance of sulphur in silicic subduction-related magmas. J Petrol 45:855-881. https://doi.org/10.1093/petrology/egg114

Cottrell E, Gardner JE, Rutherford MJ (1999) Petrologic and experimental evidence for the movement and heating of the pre-eruptive Minoan rhyodacite (Santorini, Greece). Contrib Mineral Petrol 135:315-331. https://doi.org/10.1007/s004100050514

De Capitani L, Liborio G (1990) Cummingtonite nelle plutoni ti della Val Blandino (Como). Rendiconti Lincei 1:379-385. https://doi. org/10.1007/BF03001772

Del Moro A, Ferrara G, Tonarini S, Callegari E (1983) Rb-Sr systematics on rocks from the Adamello batholith (Southern Alps). Memoria della Società Geologica Italiana 26:261-284

Eggler DH (1972) Water-saturated and undersaturated melting relations in a Paricutin andesite and an estimate of water-content in natural magma. Contrib Mineral Petrol 34:261-271. https://doi. org/10.1007/BF00373757

Eggler DH, Burnham CW (1973) Crystallization and fractionation trends in the system andesite- $\mathrm{H}_{2} \mathrm{O}-\mathrm{CO}_{2}-\mathrm{O}_{2}$ at pressures to $10 \mathrm{~kb}$. Geol Soc Am Bull 84:2517-2532. https://doi.org/10.1130/00167606(1973)84\%3c2517:CAFTIT\%3e2.0.CO;2

Evans BW, Ghiorso MS (1995) Thermodynamics and Petrology of Cummingtonite. Am Mineral 80:649-663. https://doi. org/10.2138/am-1995-7-805

Ewart A, Hildreth W, Carmichael ISE (1975) Quaternary acid magma in New-Zealand. Contrib Mineral Petrol 51:1-27. https://doi. org/10.1007/BF00403509

Fiedrich AM, Bachmann O, Ulmer P, Deering CD, Kunze K, Leuthold J (2017) Mineralogical, geochemical, and textural indicators of crystal accumulation in the Adamello Batholith (Northern Italy). Am Mineral 102:2467-2483. https://doi.org/10.2138/ am-2017-6026

Floess D, Baumgartner LP (2015) Constraining magmatic fluxes through thermal modelling of contact metamorphism. Geological Society London Special Publications 422:41-56. https://doi. org/10.1144/SP422.8

Gardner JE, Rutherford M, Carey S, Sigurdsson H (1995) Experimental constraints on pre-eruptive water contents and changing magma storage prior to explosive eruptions of Mount St Helens volcano. Bull Volcanol 57:1-17. https://doi.org/10.1007/BF00298703

Gervasoni F, Klemme S, Rocha-Júnior ERV, Berndt J (2016) Zircon saturation in silicate melts: a new and improved model for aluminous and alkaline melts. Contrib Mineral Petrol 171:21. https ://doi.org/10.1007/s00410-016-1227-y

Geschwind CH, Rutherford MJ (1992) Cummingtonite and the evolution of the Mount St-Helens (Washington) magma system: an experimental study. Geology 20:1011-1014. https ://doi.org/10.1130/0091-7613(1992)020\%3c1011:CATEO $\mathrm{T} \% 3 \mathrm{e} 2.3 . \mathrm{CO} ; 2$

Ghiorso MS, Gualda GAR (2015) $\mathrm{An}_{2} \mathrm{O}-\mathrm{CO}_{2}$ mixed fluid saturation model compatible with rhyolite-MELTS. Contrib Mineral Petrol 169:53. https://doi.org/10.1007/s00410-015-1141-8

Ghiorso MS, Evans BW, Hirschmann MM, Yang HX (1995) Thermodynamics of the amphiboles: $\mathrm{Fe}-\mathrm{Mg}$ cummingtonite solidsolutions. Am Mineral 80:502-519. https://doi.org/10.2138/ am-1995-5-612

Gill J (1981) Orogenic andesites and plate tectonics. Springer Verlag, Berlin

Goldstein JI, Newbury DE, Echlin P, Joy DC, Fiori C, Lifshin E (1981) Scanning electron microscopy and $\mathrm{x}$-ray microanalysis: a text for biologists, materials scientists, and geologists. Plenum Press, New York

Green TH (1972) Crystallization of calc-alkaline andesite under controlled high-pressure hydrous conditions. Contrib Mineral Petrol 34:150-166. https://doi.org/10.1007/BF00373770

Grove TL, Kinzler RJ, Bryan WB (1992) Fractionation of mid-ocean ridge basalt (MORB). Geophys Monogr Ser 71:281-310. https ://doi.org/10.1029/GM071p0281

Grove TL, Elkins-Tanton LT, Parman SW, Chatterjee N, Muntener O, Gaetani GA (2003) Fractional crystallization and mantle-melting controls on calc-alkaline differentiation trends. Contrib Mineral Petrol 145:515-533. https://doi.org/10.1007/s00410-003-0448-z

Gualda GAR, Ghiorso MS, Lemons RV, Carley TL (2012) RhyoliteMELTS: a modified calibration of MELTS optimized for silicarich, fluid-bearing magmatic systems. J Petrol 53:875-890. https ://doi.org/10.1093/petrology/egr080

Guillong M, Meier DL, Allan MM, Heinrich CA, Yardley BWD (2008) Appendix A6: SILLS: A Matlab-based program for the reduction of laser ablation ICP-MS data of homogeneous materials 
and inclusions. In: Mineralogical Association of Canada Short Course Volume 40. Vancouver B. C., pp 328-333

Hammer JE, Rutherford MJ, Hildreth W (2002) Magma storage prior to the 1912 eruption at Novarupta, Alaska. Contrib Mineral Petrol 144:144-162. https://doi.org/10.1007/s00410-002-0393-2

Hirose K, Kushiro I (1993) Partial melting of dry peridotites at highpressures-determination of compositions of melts segregated from peridotite using aggregates of diamond. Earth Planet Sc Lett 114:477-489. https://doi.org/10.1016/0012-821X(93)90077 $-\mathrm{M}$

Holland T, Blundy J (1994) Non-ideal interactions in calcic amphiboles and their bearing on amphibole-plagioclase thermometry. Contrib Mineral Petrol 116:433-447. https://doi.org/10.1007/ BF00310910

Holloway JR, Burnham CW (1972) Melting relations of basalt with equilibrium water pressure less than total pressure. J Petrol 13:129. https://doi.org/10.1093/petrology/13.1.1

Holtz F, Sato H, Lewis J, Behrens H, Nakada S (2005) Experimental petrology of the 1991-1995 Unzen dacite, Japan. Part I: Phase relations, phase composition and pre-eruptive conditions. J Petrol 46:319-337. https://doi.org/10.1093/petrology/egh077

Hurlimann N, Muntener O, Ulmer P, Nandedkar R, Chiaradia M, Ovtcharova M (2016) Primary magmas in continental arcs and their differentiated products: petrology of a post-plutonic dyke suite in the Tertiary Adamello Batholith (Alps). J Petrol 57:495533. https://doi.org/10.1093/petrology/egw016

Johannes W (1980) Metastable melting in the granite system QzOr-Ab-An- $\mathrm{H}_{2} \mathrm{O}$. Contrib Mineral Petrol 72:73-80. https://doi. org/10.1007/BF00375569

Kay RW, Kay SM (1991) Creation and destruction of lower continental crust. Geol Rundsch 80:259-278. https://doi.org/10.1007/BF018 29365

Lange RA, Carmichael ISE (1987) Densities of $\mathrm{Na}_{2} \mathrm{O}-\mathrm{K}_{2} \mathrm{O}-\mathrm{CaO}-\mathrm{MgO}-\mathrm{FeO}-\mathrm{Fe}_{2} \mathrm{O}_{3}-\mathrm{Al}_{2} \mathrm{O}_{3}-\mathrm{TiO}_{2}-\mathrm{SiO}_{2}$ liquids: new measurements and derived partial molar properties. Geochim Cosmochim Ac 51:2931-2946. https://doi.org/10.1016/00167037(87)90368-1

Lindsley DH (1983) Pyroxene thermometry. Am Mineral 68:477-493

Lowenstern JB (2001) Carbon dioxide in magmas and implications for hydrothermal systems. Miner Deposita 36:490-502. https://doi. org/10.1007/s001260100185

Macera P, Ferrara G, Pescia A, Callegari E (1983) A geochemical study on the acid and basic rocks of the Adamello Batholith. Memoria della Società Geologica Italiana 26:223-259

Martel C, Pichavant M, Holtz F, Scaillet B, Bourdier JL, Traineau $\mathrm{H}$ (1999) Effects of $\mathrm{fO}_{2}$ and $\mathrm{H}_{2} \mathrm{O}$ on andesite phase relations between 2 and 4 kbar. J Geophys Res-Sol Ea 104:29453-29470. https://doi.org/10.1029/1999JB900191

Moore G, Carmichael ISE (1998) The hydrous phase equilibria (to 3 kbar) of an andesite and basaltic andesite from western Mexico: constraints on water content and conditions of phenocryst growth. Contrib Mineral Petrol 130:304-319. https://doi. org/10.1007/s004100050367

Muntener O, Kelemen PB, Grove TL (2001) The role of $\mathrm{H}_{2} \mathrm{O}$ during crystallization of primitive arc magmas under uppermost mantle conditions and genesis of igneous pyroxenites: an experimental study. Contrib Mineral Petrol 141:643-658. https://doi. org/10.1007/s004100100266

Nandedkar RH, Ulmer P, Muntener O (2014) Fractional crystallization of primitive, hydrous arc magmas: an experimental study at 0.7 GPa. Contrib Mineral Petrol 167:1015. https://doi.org/10.1007/ s00410-014-1015-5

Nandedkar RH, Hurlimann N, Ulmer P, Muntener O (2016) Amphibole-melt trace element partitioning of fractionating calc-alkaline magmas in the lower crust: an experimental study. Contrib Mineral Petrol 171:71. https://doi.org/10.1007/s00410-016-1278-0
Nimis P, Ulmer P (1998) Clinopyroxene geobarometry of magmatic rocks Part 1: an expanded structural geobarometer for anhydrous and hydrous, basic and ultrabasic systems. Contrib Mineral Petrol 133:122-135. https://doi.org/10.1007/s004100050 442

O’Neill HSC, Pownceby MI (1993) Thermodynamic data from redox reactions at high temperatures. 1 . An experimental and theoretical assessment of the electrochemical method using stabilized zirconia electrolytes, with revised values for the Fe-"FeO", $\mathrm{Co}-$ $\mathrm{CoO}, \mathrm{Ni}-\mathrm{NiO}$ and $\mathrm{Cu}-\mathrm{Cu}_{2} \mathrm{O}$ oxygen buffers, and new data for the W-WO 2 buffer. Contrib Mineral Petrol 114:296-314. https://doi. org/10.1007/BF01046533

Pichavant M, Costa F, Burgisser A, Scaillet B, Martel C, Poussineau S (2007) Equilibration scales in silicic to intermediate magmasImplications for experimental studies. J Petrol 48:1955-1972. https://doi.org/10.1093/petrology/egm045

Pistone M, Caricchi L, Ulmer P, Reusser E, Ardia P (2013) Rheology of volatile-bearing crystal mushes: mobilization vs. viscous death. Chem Geol 345:16-39. https://doi.org/10.1016/j.chemg eo.2013.02.007

Piwinskii AJ (1968) Experimental studies of igneous rock series Central Sierra Nevada Batholith, California. J Geol 76:548-570. https://doi.org/10.1086/627359

Piwinskii AJ (1973) Experimental studies of granitoids from the Central and Southern Coast Ranges, California. Tschermaks Mineralogische und Petrologische Mittteilungen 20:107-130. https:// doi.org/10.1007/BF01081387

Piwinskii AJ (1975) Experimental studies of granitoid rocks near the San Andreas fault zone in the Coast and Transverse Ranges and Mojave-Desert, California. Tectonophysics 25:217-231. https:// doi.org/10.1016/0040-1951(75)90028-1

Piwinskii AJ, Martin RF (1970) Experimental study of equilibrium with granitic rocks at $10 \mathrm{~kb}$. Contrib Mineral Petrol 29:1-10. https://doi.org/10.1007/BF00387994

Pownceby MI, O'Neill HSC (2000) Thermodynamic data from redox reactions at high temperatures. VI. Thermodynamic properties of $\mathrm{CoO}-\mathrm{MnO}$ solid solutions from emf measurements. Contrib Mineral Petrol 140:28-39. https://doi.org/10.1007/s004100000162

Ratajeski K, Sisson TW (1999) Loss of iron to gold capsules in rockmelting experiments. Am Mineral 84:1521-1527. https://doi. org/10.2138/am-1999-1005

Reusser E (1987) Phasenbeziehungen im Tonalit der Bergeller Intrusion. Swiss Bull Mineral Petro 67:377-379

Ridolfi F, Renzulli A (2012) Calcic amphiboles in calc-alkaline and alkaline magmas: thermobarometric and chemometric empirical equations valid up to $1,130 \&$ \#xB0;C and $2.2 \mathrm{GPa}$. Contrib Mineral Petrol 163:877-895. https://doi.org/10.1007/s0041 0-011-0704-6

Ridolfi F, Renzulli A, Puerini M (2010) Stability and chemical equilibrium of amphibole in calc-alkaline magmas: an overview, new thermobarometric formulations and application to subductionrelated volcanoes. Contrib Mineral Petrol 160:45-66. https://doi. org/10.1007/s00410-009-0465-7

Rudnick RL (1995) Making continental crust. Nature 378:571-578. https://doi.org/10.1038/378571a0

Rutherford MJ, Devine JD (2003) Magmatic conditions and magma ascent as indicated by hornblende phase equilibria and reactions in the 1995-2002 Soufriere Hills magma. J Petrol 44:1433-1454. https://doi.org/10.1093/petrology/44.8.1433

Scaillet B, Evans BW (1999) The 15 June 1991 eruption of Mount Pinatubo. I. Phase equilibria and pre-eruption P-T- $\mathrm{fO}_{2}-\mathrm{fH}_{2} \mathrm{O}$ conditions of the dacite magma. J Petrol 40:381-411. https:// doi.org/10.1093/petroj/40.3.381

Scaillet B, Pichavant M, Roux J (1995) Experimental crystallization of leucogranite magmas. J Petrol 36:663-705. https://doi. org/10.1093/petrology/36.3.663 
Schaltegger U et al (2009) Zircon and titanite recording 1.5 million years of magma accretion, crystallization and initial cooling in a composite pluton (southern Adamello batholith, northern Italy). Earth Planet Sc Lett 286:208-218. https://doi.org/10.1016/j. eps1.2009.06.028

Schmitt AK, Lindsay JM, de Silva S, Trumbull RB (2003) U-Pb zircon chronostratigraphy of early-Pliocene ignimbrites from La Pacana, north Chile: implications for the formation of stratified magma chambers. J Volcanol Geoth Res 120:43-53. https://doi. org/10.1016/S0377-0273(02)00359-1

Sekine T, Katsura T, Aramaki S (1979) Water saturated phase-relations of some andesites with application to the estimation of the initial temperature and water-pressure at the time of eruption. Geochim Cosmochim Ac 43:1367-1376. https://doi.org/10.1016/00167037(79)90127-3

Shane P, Nairn IA, Smith VC (2005) Magma mingling in the similar to $50 \mathrm{ka}$ Rotoiti eruption from Okataina Volcanic Centre: implications for geochemical diversity and chronology of large volume rhyolites. J Volcanol Geoth Res 139:295-313. https:// doi.org/10.1016/j.jvolgeores.2004.08.012

Sisson TW, Grove TL (1993) Experimental investigations of the role of $\mathrm{H}_{2} \mathrm{O}$ in calc-alkaline differentiation and subduction zone magmatism. Contrib Mineral Petrol 113:143-166. https://doi. org/10.1007/BF00283225

Smith DR, Leeman WP (1982) Mineralogy and phase chemistry of Mount St. Helens tephra sets $\mathrm{W}$ and $\mathrm{Y}$ as keys to their identification. Quaternary Res 17:211-227. https://doi.org/10.1016/00335894(82)90059-X

Spear FS, Kimball KL (1984) RECAMP - a FORTRAN-IV program for estimating $\mathrm{Fe}^{3+}$ contents in amphiboles. Comput Geosci 10:317-325. https://doi.org/10.1016/0098-3004(84)90029-3

Speidel DH, Osborn EF (1967) Element distribution among coexisting phases in system $\mathrm{MgO}-\mathrm{FeO}-\mathrm{Fe}_{2} \mathrm{O}_{3}-\mathrm{SiO}_{2}$ as a function of temperature and oxygen fugacity. Am Mineral 52:1139-1152
Taylor JR, Wall VJ, Pownceby MI (1992) The calibration and application of accurate redox sensors. Am Mineral 77:284-295

Ulmer P (2007) Differentiation of mantle-derived calc-alkaline magmas at mid to lower crustal levels: experimental and petrologic constraints. Period Mineral 76:309-325

Ulmer P, Callegari E, Sonderegger U (1983) Genesis of the mafic and ultramafic rocks and their genetical relations to the tonalitictrondhjemitic granitoids of the southern part of the Adamello batholith (Northern Italy). Memorie della Società Geologica Italiana 26:171-222

Ulmer P, Kaegi R, Muntener O (2018) Experimentally derived intermediate to silica-rich arc magmas by fractional and equilibrium crystallization at $1.0 \mathrm{GPa}$ : an evaluation of phase relationships, compositions, liquid lines of descent and oxygen fugacity. J Petrol 59:11-58. https://doi.org/10.1093/petrology/egy017

Verberne R (2013) The role of magma rheology during emplacement of the Listino Suite, Adamello Massif, Italy. PhD Thesis, University of Lausanne

Vigneresse JL, Barbey P, Cuney M (1996) Rheological transitions during partial melting and crystallization with application to felsic magma segregation and transfer. J Petrol 37:1579-1600. https:// doi.org/10.1093/petrology/37.6.1579

Watson EB, Harrison TM (1983) Zircon saturation revisited: temperature and composition effects in a variety of crustal magma types. Earth Planet Sc Lett 64:295-304. https://doi.org/10.1016/0012821X(83)90211-X

Wyllie PJ, Huang WL, Stern CR, Maaloe S (1976) Granitic magmaspossible and impossible sources, water contents, and crystallization sequences. Can J Earth Sci 13:1007-1019. https://doi. org/10.1139/e76-104

Publisher's Note Springer Nature remains neutral with regard to jurisdictional claims in published maps and institutional affiliations. 